\title{
MICHELE SPINICCI
}

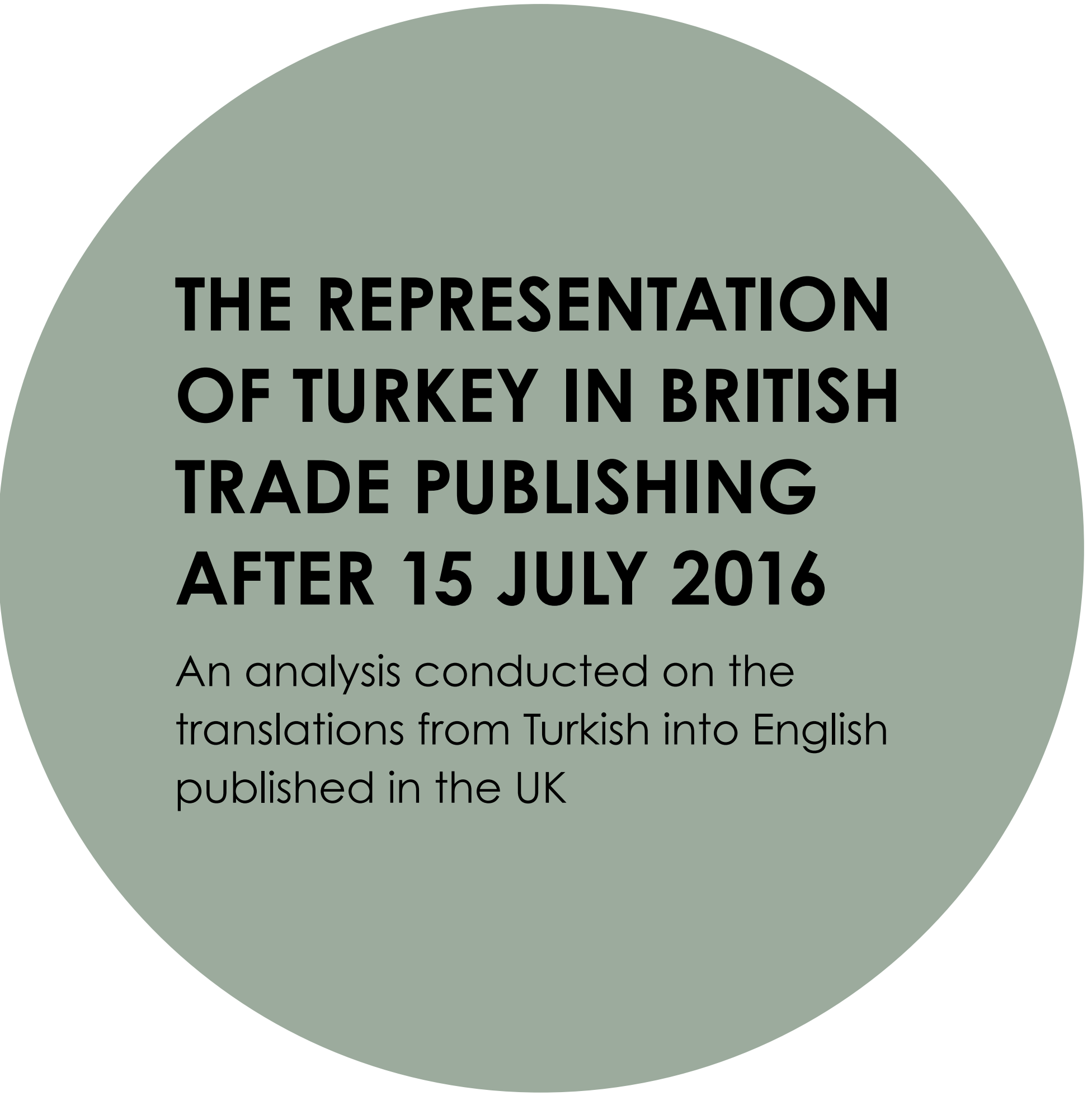

KEYWORDS:

REPRESENTATION, TURKEY, TRADE PUBLISHING, TRANSLATION, UK 


\section{ABSTRACT}

After the failed military coup in 2016 , the Turkish government implemented a series of measures that strongly restricted democratic freedoms in the country. In the UK, this event caused the media to propose a representation of the nation in which the coup and the government's reaction, together with the concepts of authoritarianism and censorship, played a central part. The present article aims to understand which role British trade publishing played in this new representation, analysing all the translations of trade titles from Turkish into English published by British publishers in the UK, comparing the periods before-between 1 January 2012 to 15 July 2016and after the coup-from 16 July 2016 to 31 December 2019. Moreover, it tries to understand if some pivotal socio-political events of contemporary Turkey, as the coup and its aftermath, the Kurdish conflict, and the Turkish intervention in the Syrian war, have had more space in the translations published in the UK after the coup. It also investigates if, after the coup, the choice of titles and authors to translate has been influenced, and if given epitextual elements-specifically books' descriptions on the publishers' websites-have shown a tendency of being linked to Turkey's contemporary socio-political situation. It then presents an evaluation of the behaviour of trade publishers in the UK toward the coup and their new focus on the democratic question in Turkey.

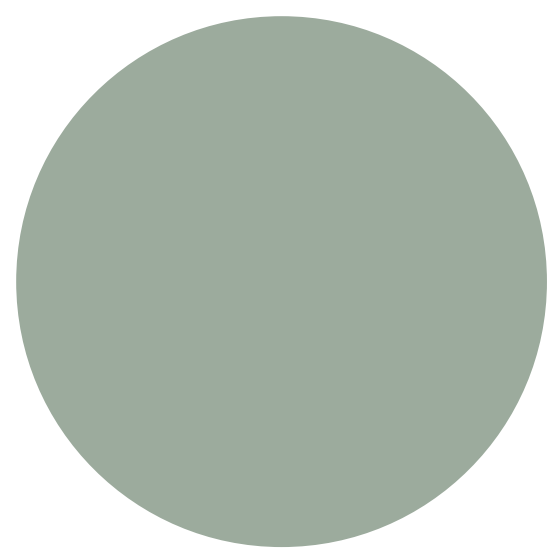




\section{Licence agreement}

(C) 2021 Michele Spinicci. This article is distributed under the terms of the Creative Commons Attribution Licence

(CC-BY) 4.0 https://creativecommons.org/licences/by/4.0/, which permits unrestricted use, distribution, and reproduction in any medium, provided the original author and source are credited.

\section{Peer review}

This article has been peer reviewed through the journal's standard double-blind peer review, where both the reviewers and authors are anonymised during review.

\section{Article type}

Research Article

\section{How to cite this article}

Spinicci, Michele, 'The representation of Turkey in British trade publishing after 15 July 2016. An analysis conducted on the translations from Turkish into English published in the UK', Interscript Journal, 4.6 (2021), pp. 1-37.

\section{$\mathrm{DO}$}

$10.14324 / 111.444 .2398-4732.1212$

\section{Author affiliation}

Bachelor Humanities | Università degli Studi| Italy MA Publishing | UCL | UK

Currently studying Modern Humanities at the Università degli Studi of Milan.

\section{First published}

01 October 2021 


\section{Author biography}

\section{Michele Spinicci}

Michele Spinicci was born in Milan in 1995. He has a Bachelor in Humanities from the Università degli Studi of Milan and an MA in Publishing from UCL. His main research interests are the relationships between politics and culture, and the mechanisms of censorship. $\mathrm{He}$ is currently working in the editorial department of an Italian trade publishing house.

_-Twitter: @MicheleSpinicci 


\section{FULL ARTICLE}

\section{INTRODUCTION'}

During the night of 15 July 2016, in Turkey, a faction of the army unsuccessfully attempted a coup d'état. ${ }^{2}$ As a reaction, the government, led by the conservative, nationalist, and Islamist ${ }^{3}$ Prime Minister Recep Tayyip Erdoğan, implemented a series of measures that strongly restricted democratic freedoms in the country, ${ }^{4}$ notably the freedom of speech and of expression. ${ }^{5}$ The Turkish 'democratic breakdown'6 caused more tense relations between Turkey and the main Western democracies.' Moreover, the perception of the former in the latter's public discourse was impacted, with the concepts of authoritarianism and censorship more often associated with Turkey. ${ }^{8}$ In the UK, the representation of Turkey offered by the media was remarkably influenced by the coup and its aftermath. Not only these events received significant coverage in the UK, but they contributed to changing the image British media conveyed of Turkey. The concepts of conflict and oppression became dominant in the British public description of the country. ${ }^{9}$

This article will analyse the reaction of a particular UK media: trade publishing. It will examine the translations from Turkish into English published by British publishing houses during two time periods: between 1 January 2012 and 15 July 2016, and between 16 July 2016 and 31 December 2019. Analysing which titles and which authors have been translated then, and how these titles have been presented by

$1 \quad$ This article is based on the author's MA dissertation, and cites data and findings already exposed there.

2 Kaya Genç, Under the Shadow: Rage and Revolution in Modern Turkey (London: I.B. Taurus, 2016) p. 215.

3 Halil M. Karaveli, 'The Rise and Rise of the Turkish Right', New York Times, 8 April $2019<$ https:// www.nytimes.com/2019/04/08/opinion/turkey-nationalism-right-wing.html> [Accessed 3 March 2021].

4 See Part 1.

5 For a complete account of the measures that have restricted freedom of speech and expression in Turkey after 2016, see: Yaman Akdeniz, and Kerem Altıparmak, Turkey: Freedom of Expression in Jeopardy (London: English PEN, 2018).

$6 \quad$ Murat Somer, 'Understanding Turkey's democratic breakdown: old vs. new and indigenous vs. global authoritarianism', in Southeast European and Black Sea Studies, volume 16, 2016, p. 448.

$7 \quad$ Philippe Perchoch, Future EU-Turkey Relations (Strasburg: European Parliamentary Research Service) pp. 1-4; See also: Abigail Hauslohner, Karen DeYoung and Valerie Strauss, 'He's 77, Frail and Lives in Pennsylvania. Turkey Says He's a Coup Mastermind', Washington Post, 3 August 2016 <https:// www.washingtonpost.com/national/hes-frail-77-and-lives-in-pennsylvania-turkey-says-hes-a-coupmastermind/2016/08/03/6bl b2226-526f-1 le6-bbf5-957ad17b4385_story.html? utm_term=.05dcbdd3a15f> [Accessed 13 March 2021].

8 Senem B. Çevik, 'Reassessing Turkey's Soft Power: The Rules of Attraction', Alternatives: Global, Local, Political, Vol. 44(1), 2019, pp. 50-65.

9 Şebnem Cansun and Engin Arık, 'Representations of countries in the international media: The case of Turkey in the BBC', Journal of the Human and Social Science Researches, volume 8, issue 1,

2019, p. 531-532. 
the British publishers, the article aims to understand if the British trade publishing industry has been influenced-or contributed to shaping-a representation of Turkey affected by the country's recent socio-political developments. Specifically, it will investigate if there has been an increment in the translations specifically focused on the state of Turkish democracy and other topics strictly connected to the representation of Turkey as an authoritarian state, like the repression of Kurdish minorities and the country's participation in the Syrian conflict. It will analyse how British publishers have presented these developments to their readers and which position they implicitly and explicitly expressed about them. Finally, it will propose a cultural and ideological evaluation of how British publishers reacted to the 2016 coup attempt through their translations.

Overall, the purpose of this article is to provide a contribution to the analysis of the cultural perception of modern Turkey and the interactions between sociopolitical events and culture, mediated by a cultural industry such as the trade publishing system.

\section{METHODOLOGY}

The data presented and analysed in this study-trade books translated from Turkish and published by British publishers in the UK-have been kindly provided by the British Library. They include all the books published in the UK between 1 January 2012 and 31 December 2019 for which Turkish is the original language. As advised by the British Library, their server does not report the original language for every translated book. Therefore, some translations might be missing from the list.

Consequently, the sources have been integrated using Nielsen Bookscan. All the results for books published in the UK by the authors listed in the British Library's report have been included, in order to encompass all these authors' publications. Moreover, the data from 2012 have been compared with the ones reported in Tekgül's and Akbatur's Literary Translation from Turkish into English in the United Kingdom and Ireland, 1990-2012. ${ }^{10}$ Finally, the results have been compared with the list of TEDA grants" books provided by the Turkish government-accorded to British publishers.

10 Duygu Tekgül, Literary Translation from Turkish into English in the United Kingdom and Ireland, 1990-2012, ; updated by Arzu Akbatur (Aberystwyth: Literature Across Frontiers, 2013).

11 'Published Works', Republic of Turkey Ministry of Culture and Tourism, n.a. <https://teda.ktb. gov.tr/EN-252216/published-works.html> [Accessed 6 September 2020]. 
The dates for the books' publication in the UK are from Nielsen Bookscan. When more than one publication date was reported for a single title, for example if a title has been published in paperback and hardback editions, only the first date in chronological order was considered.

For the purposes of this study, only trade titles were taken into account. Of course, the difference between trade, academic, and professional titles always presents an unavoidable degree of ambiguity. Clark and Philips consider trade publishers the ones who 'produce books for the public', as opposed to nonconsumer publishers, who publish books that embrace 'readers' places of study and work'. ${ }^{2}$ Starting from this distinction, any title that was explicitly presented by the British publisher as suitable and addressed to a specific audience of scholars or professionals, and not to a general one, has been excluded from the analysis. Following this criterion, three titles listed by the British Library were indeed excluded, as they were deemed academic publications. ${ }^{13}$

In the article, 15 July 2016 is considered a date after which a different representation of Turkey is likely to have been proposed by foreign media. The coup has been a major divide in Turkey's modern history and its immediate aftermath has seen a remarkable, quick, and abrupt decline in the level of democracy in the country ${ }^{14}$ and the event received significant international media coverage. ${ }^{15}$

In Turkey's recent history, under the rule of the AKP more precisely, there have been other events with serious repercussions on the state of human rights and democracy in the country, as the repression of the Gezi Park protests, and the end of the Peace Process between the Turkish government and the Kurdish movement. It is not the purpose of this article to establish which of these events have had the greatest impact on the structure of Turkish society and the state of human rights in the country. What matters here is how deeply the events influenced the international perception and representation of Turkey. Furthermore, the failed coup and its aftermath seem to be the episodes that received the highest attention from international media, even if there is no precise data about it.

The article investigates if British publishers, through their translations, dedicated different attention to three topics: the state of Turkish democracy; the repression of the Kurdish minority in Turkey; and the Turkish intervention in the Syrian conflict.

\footnotetext{
12 Giles Clark and Angus Phillips, Inside Book Publishing (London: Routledge, 2014), p. 4.

13 See the appendix.

14 For example: in the Freedom House index, Turkey's score passed from 65 to 71 (a smaller score corresponds to greater freedom of the press). See: 'Publication Archives', Freedom House, n.a.<https://freedomhouse.org/reports/publication-archives> [Accessed 1 September 2020].
}

15 As an example, Domenico Fracchiolla has highlighted 228 articles on 8 national newspapers (two each for Italy, Germany, France, UK) in the 16 days following the coup, which had that event as their central focus. See: Domenico Fracchiolla, 'Journalism Models in Western Democracies and the International Arena: The Case of the 2016 Failed Coup Attempt in Turkey', Partecipazione e Conflitto, Vol. 13, Issue 3, 2020, 1559-1574, p. 1566. 
The date of 15 July 2016 is strictly connected to the first topic only. ${ }^{16}$ That being said, the coup attempt has been a major event which has attracted international attention on all the aspects of the Turkish political system, geopolitical interactions, and respect for human rights. Thus, it seems appropriate to extend the field of analysis to the Kurdish and Syrian issues, two of the most representative of modern Turkey for British media.

The timeframe stretching between 1 January 2012 and 31 December 2019 was chosen in order to analyse the last four years leading to the coup and the State of Emergency in Turkey, which lasted from 2012 to 2015, and the four years that followed. However, this period of time has been divided into two sections, from 1 January 2012 to 15 July 2016 and from 16 July 2016 to 31 December 2019.

As it happens, a book can be selected by a foreign publisher to be translated and published months, or even years, before the original publication date. Therefore, there might be post-coup translations from Turkish which appear to have been influenced by the events of 15 July but were selected before that date, reflecting a will by British publishers to commercialize a title known to their domestic audience prior to the coup and its aftermath. When this case seemed to recur in the article for a specific title, it was clearly highlighted. Moreover, the present paper also examines the epitextual elements of the translations, which typically reflect how a publisher presents a book to reinforce its publication. This should lower the risk of incorrectly associating a book published after the coup to have been inspired by the event.

Finally, it ought to be said that for the sake of this article, even translations from other languages to English but whose original language was Turkish have been considered translations "from Turkish into English". To illustrate this statement, Sakine Cansiz's memoirs were first published in Turkish in 2014, translated in German in 2015, then translated from German into English and published in two different volumes by Pluto Press in 2018 and $2019.1^{17}$ In addition, titles written in Turkish and published in another country were also considered this research, such as Ahmet Altan's 1 Will Never See the World Again, published by Granta in 2019, with a translation by Yasemin Çongar. Because of Altan's imprisonment for having participated in the coup, the book was published outside Turkey. ${ }^{18}$

16 Of course, this does not mean that the aftermath of the 15 July coup attempt did not have repercussions on the other two topics. In particular, the condition and the respect of the rights of the Kurdish minority in Turkey has been gravely impacted by the measures implemented by the Turkish government after the coup. See for example: Mert Arslanalp and T. Deniz Erkmen, 'Repression without Exception: A Study of Protest Bans during Turkey's State of Emergency' (2016-2018), South European Society and Politics, volume 25, issue 1, 2020, pp. 99-125, p. 108; see also: Harun Ercan, 'Is Hope More Precious than Victory? The Failed Peace Process and Urban Warfare in the Kurdish Region of Turkey', South Atlantic Quarterly, volume 118, issue 1, 2019, pp. 110-127, p. 112.

17 Agnes von Alvensleben, Anja Flach, 'Who was Sakine Cansiz?' Pluto Press, n.a. <https://www. plutobooks.com/blog/who-was-sakine-cansiz/> [Accessed 1 July 2021].

18 Kareem Shaheen, 'Turkey Sentences Journalists to Life in Jail over Coup Attempt', Guardian, 16 February $2018<$ https://www.theguardian.com/world/2018/feb/16/turkey-sentences-six-journalists-life-imprisonment-failed-coup $>$ [Accessed 12 September 2020]. 
Analysing the translations from Turkish is only a first step to understanding the cultural impact of the coup and its aftermath on the British publishing industry. Other publications should have been studied, including works focusing or citing Turkey during this period, but the hope is that this article encourages future analyses of the Turkish socio-political and cultural history.

\section{THE COUP, ITS AFTERMATH, AND THE INTERNATIONAL REACTION}

In the late evening of 15 July 2016, a faction of the Turkish army started a series of military actions to topple the government and take authority. However, the majority of the military remained loyal to the government, and many thousands of citizens took to the streets to rebel against the putschists. ${ }^{19}$ By dawn, it was clear that the coup had failed. 700 plotters were arrested, but the conflict made over 200 victims, the majority of which were civilians..$^{20}$ Although it was immediately declared that the coup was led by the powerful preacher Fetullah Gülen and his followers, ${ }^{21}$ his involvement is still debated. ${ }^{22}$

19 Maximilian Popp, 'Revisiting Turkey's Failed Coup Attempt', Spiegel International, 6 July 2017 <https://www.spiegel.de/international/world/turkey-coup-a-chronology-of-events-a-1 155762.html> [Accessed 21 March 2021].

20 The number of casualties is unclear: according to the Turkish government, the death toll is 312 , with 145 civil casualties. See: AFP (pseudonym), 'Erdogan Back in Ankara as Thousands Hit by Turkey Purge', Guardian, 20 July 2016 <https://guardian.ng/news/erdogan-back-in-ankara-as-thousands-hitby-turkey-purge/> [Accessed 20 July 2020]; However, Gunter states that 272 people died, including 171 civilians. See: Michael Gunter, 'Turkey's July 15th Coup: What Happened and Why', Middle East Policy Council <https://mepc.org/turkeys-july-15th-coup-what-happened-and-why> [Accessed 3 July 2020]; The Time of Israel reported 246 deaths, including 179 civilians. See: Franz Zeller and Stuart William, 'Turkey Shuts 1,000 Schools, Arrests Wanted Cleric's Nephew', Time of Israel, 23 July 2016, <https://www.timesofisrael.com/turkey-shuts-1000-school-arrests-wanted-clerics-nephew/> [Accessed 20 July 2020].

21 'Turkey Timeline: Here's How the Coup Attempt Unfolded', Al Jazeera, 16 July 2016 <https:// www.aljazeera.com/news/2016/07/turkey-timeline-coup-attempt-unfolded-160716004455515.html> [Accessed 20 March 2021].

22 The debate about the Gülen Movement's involvement in the coup is still very lively, with trustworthy scholars sustaining radically different and irreconcilable positions. As an example, Haliloglu believes in a full involvement of the movement. See: Nagihan Haliloglu, 'Trauma, Historical Symbolism and the Return of the Repressed: The 15 July 2016 Coup Attempt in Turkey', Asian Affairs, Volume 48, Issue 1, 2017, pp. 1-16, p. 1. While an article published in Strategic Comments deems it as unlikely. See: 'Turkey: The Attempted Coup and its Troubling Aftermath', Strategic Comments, Volume 22, Issue 5, pp. V-VII, p. VII.). Waldman and Caliskan propose a more nuanced opinion, according to which a faction of Gülenist militaries attempted a coup but Gülen himself was probably uninvolved. See: Simon Waldman and Emre Caliskan, 'Factional and Unprofessional: Turkey's Military and the July 2016 Attempted Coup', Democracy and Security, Volume 16, Issue 2, 2020, pp. 123-150 p. 139. 
Five days later, on 20 July, the Council of Ministers declared the State of Emergency (SOE). The measure was explicitly meant to dismantle the 'Gülenist network', which had allegedly penetrated every sector of the state apparatus. Supposed to last three months, the government prolonged it until 18 July $2018 .^{23}$

At the time, the authorities arrested about 100,000 people over alleged links to the military coup and on presumptions of "terror". ${ }^{24}$ They dismissed 126,000 public servants, accounting for $4.3 \%$ of the total, ${ }^{25}$ and shut down 189 media outlets for alleged connection with the Gülen movement or other terrorist organisations. ${ }^{26}$ Among them, 29 publishing houses were forced to close down. Moreover, the SoE generated a strong deterioration of the Kurdish minority's political rights, as several Kurdish politicians were arrested, as well as an increase in pro-Kurdish protest bans. ${ }^{27}$ Years after the lift of the SoE, international observers claim that the purges in Turkey continue and the declaration of such a measure has brought a permanent drift to a more authoritarian asset of the country. ${ }^{28}$

The measures implemented by the Turkish government have raised serious concerns among international observers. Such measures were considered to make impossible any form of opposition to the government ${ }^{29}$ and criticised for the excessive power they granted to the executive branch. ${ }^{30}$ Many foreign governments and NGOs have condemned the reaction to the coup. ${ }^{31}$

$23 \quad$ Kerem Altıparmak and Senem Gürol, 'Turkey's Derogation of Human Rights under the State of Emergency: Examining its Legitimacy and Proportionality', Austrian Review of International and European Law, Volume 22, Issue 1, pp. 101-136, p. 118.

24 'Turkey Post-Coup Crackdown', Turkey Purge, last updated 4 March 2019 <https://turkeypurge. com/> [Accessed 20 July 2020].

25 'How the Turkish Purge Unfolded', Wall Street Journal, n.a. < https://www.wsj.com/graphics/ turkish-purge/> [Accessed 20 July 2020].

26 'Turkey Shuts Scores of Media Outlets, Sacks Generals', Al Jazeera, 27 July 2016 <https://www.aljazeera. com/news/2016/07/turkey-close-army-high-schools-failed-coup-160727165730365.html> [Accessed 20 July 2020].

$27 \quad$ Arslanalp and Erkmen, p. 108.

28 Holly Ellyatt, 'Turkey Lifts State of Emergency but Nothing Much Has Changed, Analysts Warn', CNBC, 19 July 2018 <https://www.cnbc.com/2018/07/19/turkey-lifts-state-of-emergency-but-nothingmuch-has-changed-analysts.html> [Accessed 20 July 2020]; See also: Serkan Demirtaş, "Has Turkey Really Lifted the State of Emergency?', Hürriyet Daily News, 10 November $2018<$ https://www.hurriyetdailynews. com/opinion/serkan-demirtas/has-turkey-really-lifted-the-state-of-emergency-138738> [Accessed 20 July 2020]; 'Turkey Ends State of Emergency, But Eyes Tough Terror Bill', DW, 19 July $2018<$ https://www.dw.com/ en/turkey-ends-state-of-emergency-but-eyes-tough-terror-bill/a-44739765> [Accessed 20 July 2020].

29 Diego Cupolo, 'The State of Emergency for Turkey's Opposition', DW, 25 July 2016 <https://www. dw.com/en/the-state-of-emergency-for-turkeys-opposition/a-19426590> [Accessed 3 September 2020].

30 Ece Göztepe, 'The Permanency of the State of Emergency in Turkey: The Rise of a Constituent Power or only a New Quality of the State?', Z Politikwiss, Volume 28, 2018, pp. 521-534, p. 531.

31 See for example: Christoph Grabenwarter, Regina Kiener, Martin Kuijer, Herdís Kjerulf porgeirsdóttir, Turkey: Opinion On The Measures Provided In The Recent Emergency Decree Laws With Respect To Freedom Of The Media, (European Commission for Democracy Through Law: Strasbourg, 2017), p. 3. See also: Akdeniz and Altıparmak, 2016; and: 'Joint Statement: Turkey: State of Emergency Provisions Violate Human Rights And Should Be Revoked', Amnesty International, 19 October 2016 <https://www.amnesty.org/en/documents/eur44/5012/2016/en/> [Accessed 13 March 2021]. 
In the publishing environment, it is worth noting that the International Publishers Association condemned the 'Turkish government's remorseless purge of all critical voices, in the media, academia, and all areas of cultural life'. ${ }^{32}$ Today, the website Boycott Turkey invites academics and artists to boycott academic and cultural institutions sponsored by the Turkish government. Their petitions have been signed by thousands of academics, writers, and intellectuals, between whom are Noam Chomsky and Angela Davis. ${ }^{33}$ Between the adduced reasons to sustain the boycott, there are the Turkish government post-coup repression on the media and the military actions against the Kurdish population. ${ }^{34}$

More generally, Turkey's international perception has been affected by its democratic crisis, which negatively influenced the country's soft power. ${ }^{35}$ Moreover, Turkey's international reputation has deteriorated, particularly between Western liberal democracies-including the UK-, where its image as an authoritarian state has been bolstered. ${ }^{36}$ After what happened in 2016. Turkey's relations with these countries are considered to have generally worsened. ${ }^{37}$

\section{INFLUENCES AND CONSEQUENCES OF THE COUP ON TRADE PUBLISHING}

In the UK, at least during the months immediately after $15 \mathrm{July}$, the failed attempt and its aftermath have occupied centre stage in the mediatic representation of Turkey. Between this day and 15 July 2017, the Guardian published 615 articles regarding Turkey. Of these, 327 (53\%) explicitly cited the coup. ${ }^{38}$

A study on the representation of Turkey in the BBC between December 2016 and June 2018 showed how the country's conveyed image was almost totally dependent on the recent political developments:

32 'IPA Prix Voltaire', International Publishers Association, n.a. <https://www.internationalpublishers.org/our-work/freedom-to-publish/ipa-freedom-to-publish-prize> [Accessed 21 March 2021].

33 'Call to Boycott Turkish Government Sponsored Academic and Cultural Institutions', Boycott Turkey, n.a. <https://boycott-turkey.net/call-to-boycott-turkish-government-sponsored-academic-and-cultural-institutions-2/> [Accessed 7 September 2020].

34 'Why Boycott Turkey', Boycott Turkey, n.a.<https://boycott-turkey.net/why-boycott-turkey/> [Accessed 7 September 2020].

35 Çevik, p. 64

36 Ibid., p. 61

37 See note 8.

38 Articles published in the Guardian between 15 July 2016 and 15 July 2017, with the tag 'Turkey', that cite the coup attempt either in the title or in the text. See: 'Turkey', Guardian, n.a.<https:// www.theguardian.com/world/turkey?page=53> [Accessed 12 September 2020]. 
Turkey was represented as a country: under the control of a highly influential leader (Erdogan); experiencing tensions with the armed Kurdish groups [, involved] in the Syrian internal war [and] suffering from a failed coup attempt [...] [The] BBC used particularly three news frames: conflict (Erdogan vs. Gulen, Turkey vs. Syria, Turkey vs. armed Kurdish groups), human interest (sufferings because of terror, war and oppression) and attribution of responsibility (Erdogan as a savior). ${ }^{39}$

This paper tries to understand how another British media-trade publishingreacted to these socio-political shifts in Turkey. It analyses if such particular media conveyed a different representation of Turkey after the military coup and, in particular, if this representation was influenced by the Turkish government's growing authoritarianism, its conflict with Kurdish armies, and its involvement in the Syrian internal war.

To do so, the books translated from Turkish into English and published by British publishers in the UK between 2012 and 2019 have been analysed below. 103 new English translations of Turkish trade books were published by British publishers in the UK between 1 January 2012 and 31 December 2019. The distribution through the period is quite balanced, apart from a significant drop in the last two years. This might be at least partially explained by the struggle the Turkish publishing industry faced from 2018 on because of the country's inflation crisis. ${ }^{40}$ In any case, it is possible to say that the events of 2016 do not seem to have caused a stronger interest in Turkey and Turkish culture from British publishers.

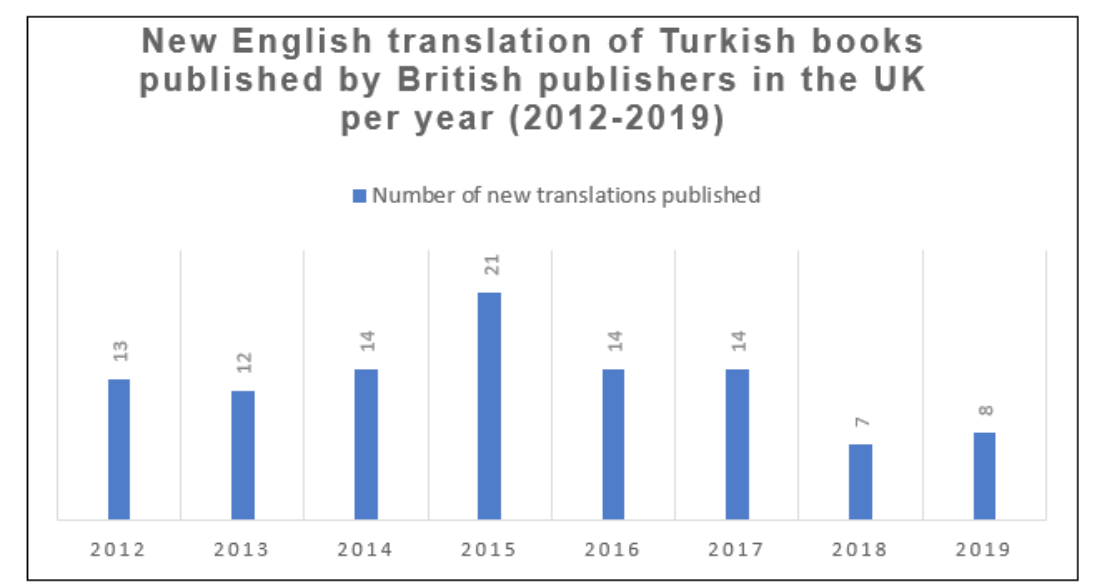

Figure 1: New English translation of Turkish books published by British publishers in the UK per year (2012-2019)

$39 \quad$ Cansun and Arık, pp. 531-532.

40 Cagan Koc and Ercan Ersoy, 'How Turkey Created a Debt Crisis', Bloomberg, 9 December 2018 <https://www.bloomberg.com/news/features/2018-12-09/how-turkey-created-a-debt-crisis> [Accessed 2 March 2021]. 
An initial method to analyse British trade publishers' tendencies toward Turkish titles is to examine the distribution of their translations by genre. During the highlighted period, 68 books were published before 15 July 2016 for the first subperiod and 35 were published after that date, that is to say during the second subperiod. Figure 2 and Figure 3 show the genres published in the two subperiods.

\begin{tabular}{|l|c|}
\hline \multicolumn{2}{|c|}{ Translated genres for 1 January 2012-15 July 2016 } \\
\hline Novels and short stories & $47(69 \%)$ \\
\hline Poetry & $8(12 \%)$ \\
\hline Religion and spirituality & $9(13 \%)$ \\
\hline Essays, biographies, memoirs & $4(6 \%)$ \\
\hline
\end{tabular}

Figure 2: Trade books translated from Turkish into English published in the UK, divided by genre (1 January 2012-15 July 2016)

\begin{tabular}{|l|c|}
\hline \multicolumn{2}{|c|}{ Translated genres for 16 July 2016-31 December 2019 } \\
\hline Novels and short stories & $14(40 \%)$ \\
\hline Poetry & $8(23 \%)$ \\
\hline Art catalogues & $1(3 \%)$ \\
\hline Religion and spirituality & $2(6 \%)$ \\
\hline Essays, biographies, memoirs & $10(29 \%)$ \\
\hline
\end{tabular}

Figure 3: Trade books translated from Turkish into English published in the UK, divided by genre (16 July 2016-31 December 2019) 
In the second subperiod, the share of fiction books decreased. On the other hand, there has been a significant growth in the translation of essays, biographies, and memoirs. ${ }^{41}$ This might suggest a stronger tendency from UK publishers to provide information about the country. In addition, the broader socio-political situation of contemporary or modern Turkey remains undiscussed in non-fiction books published in the first subperiod. By contrast, two non-fiction books of the second subperiod tackled the question of Turkish democracy, ${ }^{42}$ while two others discussed the Kurdish revolutionary movement and the Kurdish oppression in Turkey. ${ }^{43}$

Translation from Turkish specifically focused on the question of democracy in Turkey published after 15 July 2016

\begin{tabular}{|c|c|c|c|c|}
\hline Author & Title & Publisher & $\begin{array}{c}\text { Translation } \\
\text { year }\end{array}$ & $\begin{array}{c}\text { Publication } \\
\text { in Turkish }\end{array}$ \\
\hline Ece Temelkuran & $\begin{array}{c}\text { Turkey: The Insane and the } \\
\text { Melancholy }\end{array}$ & Zed Books & 2016 & 2015 \\
\hline Ahmet Altan & $\begin{array}{c}\text { I Will Never See the World } \\
\text { Again }\end{array}$ & Granta & 2019 & - \\
\hline
\end{tabular}

Figure 4: Translation from Turkish specifically focused on the question of democracy in Turkey published after 15 July 2016

Translation from Turkish specifically focused on the repression of Kurdish minority in Turkey published after 15 July 2016

\begin{tabular}{|c|c|c|c|c|}
\hline Author & Title & Publisher & $\begin{array}{c}\text { Translation } \\
\text { year }\end{array}$ & $\begin{array}{c}\text { Publication } \\
\text { in Turkish }\end{array}$ \\
\hline Sakine Cansız & $\begin{array}{c}\text { Sara: My Whole Life Was a } \\
\text { Struggle }\end{array}$ & Pluto Press & 2018 & 2014 \\
\hline Sakine Cansız & $\begin{array}{c}\text { Sara: Prison Memoir of a } \\
\text { Kurdish Revolutionary }\end{array}$ & Pluto Press & 2019 & 2014 \\
\hline
\end{tabular}

Figure 5: Translation from Turkish specifically focused on the repression of Kurdish minority in Turkey published after 15 July 2016

$41 \quad$ The article reports the genres declared on the British publishers' websites.

42 (1): Ece Temelkuran, Turkey: The Insane and the Melancholy (London: Zed Books, 2016); (2): Ahmet Altan, I Will Never See the World Again (London: Granta, 2019); (3): Ece Temelkuran, How to Lose a Country: The 7 Steps from Democracy to Dictatorship (London: Fourth Estate, 2019).

43 (1): Sakine Cansız, Sara: My Whole Life Was a Struggle (London: Pluto Press, 2018); (2): Sakine Cansız, Sara: Prison Memoir of a Kurdish Revolutionary (London: Pluto Press, 2019). 
Ece Temelkuran's book, Turkey: The Insane and the Melancholy, was published in the UK on 1 August 2016, so merely fifteen days after the coup. This means the project for its translation by Zed Books most likely started before the event. It can even be suspected that the UK publisher decided to review the book's publication date to exploit the mediatic echo of the coup.

On another hand, focusing on the second subperiod and the features of its translations, Turkey's political developments seem to have influenced the choice of authors who have been translated. Two of them, Ahmet Altan and Selahattin Demirtaş, were in prison when the translations of their books were published, accused of having been involved in the coup for Altan and of having worked with the Kurdistan Workers' Party for Demirtaş. ${ }^{44}$ Other translated authors had an important history of activism and conflict with the AKP. For example, Özgür Mumcu, author of The Peace Machine, first published in Turkish in 2016 and in English in 2019, journalist for Cumhuriyet and activist for the freedom of expression in Turkey, was trialled in 2015 for having defamed President Recep Tayyip Erdoğan in an article. ${ }^{45}$ Karin Karakaşlı, the author of the poetry book History-Geography, published in 2017 in English after a first release in Turkish, is an activist for the rights of the Armenian minority in Turkey. He was also judged in 2007 for a series of articles he wrote on 'Armenian Identity'. ${ }^{46}$ Some authors translated in subperiod two also played the role of columnists in some of the main British newspapers about the situation of democracy in Turkey. Authors like Burhan Sönmez, ${ }^{47}$ Elif \$̧afak, ${ }^{48}$ and Ece Temelkuran ${ }^{49}$ can be cited.

44 'Kurdish Leader Demirtaş Remains in Prison Despite Release Orders Due to Political Pressure, Lawyer Says', Ahval, 12 September 2020 <https://ahvalnews.com/selahattin-demirtas/kurdish-leader-demirtas-remains-prison-despite-release-orders-due-political?anguage content entity=en> [Accessed 20 March 2021].

45 'Özgür Mumcu', Pushkin Press, n.a. <https://www.pushkinpress.com/author/ozgur-mumcu/> [Accessed 13 September 2020]; See also: 'Journalist Özgür Mumcu Faces Five Years in Prison for Defaming Erdoğan', Hürriyet Daily News, 5 June 2015 < https://www.hurriyetdailynews.com/journalistozgur-mumcu-faces-five-years-in-prison-for-defaming-erdogan--83518> [Accessed 13 March 2021]. * The English editions collects the translations of poems from different Turkish poetry collections.

46 'Murdered Dink's Thoughts on Trial', English Bianet, 15 June $2007<\underline{\text { http://bianet.org/english/ }}$ print/97671-murdered-dinks-thoughts-on-trial> [Accessed 14 March 2021]. See also: 'Hrant Dink: Istanbul March as Verdict Anger Continues', BBC News, 19 January 2019 <https://www.bbc.com/news/ world-europe-16632890> [Accessed 13 March 2021].

47 Burhan Sönmez, 'President Erdoğan Is Now Targeting Anyone Who Doesn't Support Him', Guardian, 7 November 2016 <https://www.theguardian.com/commentisfree/2016/nov/07/president-erdogan-turkey-leader-crackdown-media-internet-kurdish> [Accessed 5 March 2021].

48 Elif Şafak, 'Chess Is a Troubling Metaphor as Turkey Turns to the East', Financial Times, 8 January 2018 <https://www.ft.com/content/cefc19ee-ccea-1 le6-b8ce-b9c03770f8bl> [Accessed 5 March 2021].

49 Ece Temelkuran, 'Yet Again Turkey's Children Have Awoken to Darkness at Dawn', Guardian, 17 July 2016 <https://www.theguardian.com/commentisfree/2016/jul/17/turkey-children-coup> [Accessed 6 March 2021]. 
Beside the choice of authors and texts to translate, it is important to understand how UK publishers intend to present these titles, and what elements they want to highlight. Paratextual elements can offer an interesting insight in this regard. For the purpose of this article, a focus is put on epitextual elements, ${ }^{50}$ and more specifically on the description of some books as offered on the websites of the publishers who translated them. Five of these descriptions explicitly state the democratic situation in Turkey; all in a negative and disapproving tone. ${ }^{51}$

\begin{tabular}{|c|c|c|c|c|}
\hline \multicolumn{5}{|c|}{$\begin{array}{c}\text { Turkish books translated after 15 July 2016 whose description on their British publisher's } \\
\text { website explicitly cites the situation of democracy in Turkey }\end{array}$} \\
\hline Author & Title & Publisher & $\begin{array}{c}\text { Translation } \\
\text { year }\end{array}$ & $\begin{array}{c}\text { Publication } \\
\text { in Turkish }\end{array}$ \\
\hline Ece Temelkuran & $\begin{array}{c}\text { Turkey: The Insane and the } \\
\text { Melancholy }\end{array}$ & Zed Books & 2016 & 2015 \\
\hline Özen Yula, & $\begin{array}{c}\text { Unofficial Roxelana and Other } \\
\text { Plays }\end{array}$ & $\begin{array}{c}\text { Seagull } \\
\text { Books }\end{array}$ & 2017 & $*$ \\
\hline Ahmet Altan & $\begin{array}{c}\text { Like a Sword Wound } \\
\text { Ahmet Altan }\end{array}$ & $\begin{array}{c}\text { Europa } \\
\text { Editions }\end{array}$ & 2018 & 1997 \\
\hline Sabiha Sertel, & $\begin{array}{c}\text { The Struggle for Modern Turkey: } \\
\text { Justice, Activism, and a } \\
\text { Revolutionary Female Journalist }\end{array}$ & I.B. Tauris & 2019 & 1969 \\
\hline
\end{tabular}

Figure 6: Turkish books translated after 15 July 2016 whose description on their British publisher's website explicitly cites the situation of democracy in Turkey

$50 \quad$ For the concept of epitext and its role in the paratext see: Gerard Genette, Paratexts: Thresholds of Interpretation (Cambridge: Cambridge University Press: 1997) pp. 344-370.

51 (1): Ece Temelkuran, Turkey: The Insane and the Melancholy (London: Zed Books, 2016), see: 'Turkey: The Insane and the Melancholy', Bloomsbury Publishing, n.a. <https://www.bloomsbury.com/us/turkey-9781783608898/> [Accessed 6 June 2020]; (2): Özen Yula, Unofficial Roxelana and Other Plays (London: Seagull Books, 2017), see: 'Unofficial Roxelana and Other Plays', Seagull Books, n.a. <https://www.seagullbooks.org/unofficial-roxelana/> [Accessed 13 March 2021]; (3) Ahmet Altan, Like a Sword Wound (London: Europa Editions, 2018), see: 'Like a Sword Wound', Europa Editions, n.a. <https://www.europaeditions.com/ book/9781609454\%20746/like-a-sword-wound> [Accessed 13 March 2021]; (4): Ahmet Altan, I Will Never See the World Again (London: Granta, 2019), see: 'I Will Never See the World Again', Granta, n.a. <https://granta.com/products/i-will-never-see-the-world-again/> [Accessed 13 March 2021]; (5): Sabiha Sertel, The Struggle for Modern Turkey: Justice, Activism, and a Revolutionary Female Journalist (London: I.B. Tauris, 2019), see: 'The Struggle for Modern Turkey: Justice, Activism, and a Revolutionary Female Journalist', Bloomsbury, n.a. $<$ https://www.bloomsbury.com/us/the-struggle-for-modern-turkey-9781788313575/> [Accessed 13 March 2021]; (6): Ece Temelkuran, How to Lose a Country: The 7 Steps from Democracy to Dictatorship (London: Fourth Estate, 2019), see: 'How to Lose a Country: The 7 Steps from Democracy to Dictatorship', Fourth Estate, n.a. < https://www.4thestate.co.uk/book/how-to-lose-a-country-the-7-steps-from-democracy-to-dictatorship-ece-temelkuran-9780008294045/> [Accessed 13 March 2021].

* The English edition translates plays from many different Turkish editions. 
The descriptions could also state the particular value and meaning the described book assumed when published. In the description of The Struggle for Modern Turkey, published by I.B. Tauris, it is written: 'A unique first-hand account, the text foreshadows Turkey's increasingly authoritarian state.' 52

Additionally, they can present the book as a useful text to understand the Turkish socio-political situation through the lens of literature. In the description of Unofficial Roxelana and Other Plays, published by Seagull Books, the publisher states:

[...] accomplished Turkish playwright Özen Yula offers a deep, artistic portrait of the country and its culture. Yula, whose work focuses on marginalized individuals within oppressive social systems, has a lot to say about the problems facing global democracies-issues like failures in the social contract, human rights conflicts, territorial security, religious strife, and nationalism. ${ }^{53}$

Another possibility in the presentation is to assess the importance of the book's author in Turkey's current situation. In the description of Like a Sword Wound, published by Europa Editions, it is claimed that the author, Ahmet Altan, was 'serving a life sentence on false charges', that he was a 'strong voice of dissent in his country' and that 'his arrest and conviction received widespread international criticism'. ${ }^{54}$ In addition to the reported data, four book descriptions of subperiod two cite the repression of the Kurdish minority in Turkey. ${ }^{55}$ One of them, Dawn, by Selahattin Demirtaş, also cites the war in Syria.

$52 \quad$ Sabiha Sertel, The Struggle for Modern Turkey: Justice, Activism, and a Revolutionary Female Journalist (London: I.B. Tauris, 2019), see: 'The Struggle for Modern Turkey: Justice, Activism, and a Revolutionary Female Journalist', Bloomsbury, n.a. <https://www.bloomsbury.com/us/the-struggle-formodern-turkey-9781788313575/> [Accessed 13 March 2021]

53 Özen Yula, Unofficial Roxelana and Other Plays (London: Seagull Books, 2017), see: 'Unofficial Roxelana and Other Plays', Seagull Books, n.a. <https://www.seagullbooks.org/unofficial-roxelana/> [Accessed 13 March 2021]

54 Ahmet Altan, Like a Sword Wound (London: Europa Editions, 2018), see: 'Like a Sword Wound', Europa Editions, n.a. <https://www.europaeditions.com/book/9781609454\%20746/like-a-swordwound> [Accessed 13 March 2021].

55 (1): Sakine Cansiz, Sara: My Whole Life Was a Struggle (London: Pluto Press, 2018), see: 'Sara: My Whole Life Was a Struggle', Pluto Press, n.a. <https://www.penguinrandomhouse.com/ books/588892/dawn-by-selahattin-demirtas/> [Accessed 13 March 2021]; (2): Sakine Cansız, Sara: Prison Memoir of a Kurdish Revolutionary (London: Pluto Press, 2019), see: 'Sara: Prison Memoir of a Kurdish Revolutionary', Pluto Press, n.a. <https://www.plutobooks.com/9780745339832/sara/> [Accessed 13 March 2021]; (3): Sema Kaygusuz, Every Fire You Tend (London: Tilted Axis, 2019), see: 'Every Fire You Tend, Tilted Axis, n.a. <https://www.tiltedaxispress.com/store/every-fire-you-tend-paperbackpreorder>; (4): Selahattin Demirtaş, Dawn (London: Hogarth, 2019), see: 'Dawn', Penguin Random House, n.a. <https://www.penguinrandomhouse.com/books/588892/dawn-by-selahattin-demirtas/> [Accessed 13 March 2021]. 
Turkish books translated after 15 July 2016 whose description on their British publisher's website explicitly cites the repression of the Kurdish minority in Turkey

\begin{tabular}{|l|l|l|l|l|}
\hline \multicolumn{1}{|c|}{ Author } & \multicolumn{1}{|c|}{ Title } & \multicolumn{1}{c|}{ Publisher } & \multicolumn{1}{c|}{$\begin{array}{c}\text { Translation } \\
\text { year }\end{array}$} & $\begin{array}{c}\text { Publication } \\
\text { in Turkish }\end{array}$ \\
\hline Sakine Cansız & $\begin{array}{l}\text { Sara: My Whole Life Was a } \\
\text { Struggle }\end{array}$ & Pluto Press & 2018 & 2014 \\
\hline Sakine Cansız & $\begin{array}{l}\text { Sara: Prison Memoir of a } \\
\text { Kurdish Revolutionary }\end{array}$ & Pluto Press & 2019 & 2014 \\
\hline Sema Kaygusuz & Every Fire You Tend & Tilted Axis & 2019 & 2009 \\
\hline $\begin{array}{l}\text { Selahattin } \\
\text { Demirtaş }\end{array}$ & Dawn & Hogarth & 2019 & 2017 \\
\hline
\end{tabular}

Figure 7: Turkish books translated after 15 July 2016 whose description on their British publisher's website explicitly cites the repression of the Kurdish minority in Turkey

Finally, after having examined translations' genres, the translated authors, and how their books have been presented, it is worth considering the publishers who published these translations in subperiod two. There was a remarkable presence of publishers who defined themselves as 'radical', namely Zed Books and Pluto Press, ${ }^{56}$ or attribute a particular focus to the political aspect in their presentation like Tilted Axis. ${ }^{57}$ These publishers did not publish any translation in subperiod one. This change might suggest that a deeper interest in Turkish socio-political events, and thus in Turkish literary production's socio-political aspects, attracted publishing houses specifically and explicitly focused on socio-political issues.

56 'Zed Books: Radical International Publishing', Frankfurt Rights, 2016 <https://frankfurtrights.com/ Company/39> [Accessed 27 June 2021]; 'Homepage', Pluto Press, n.a. <https://www.plutobooks. com/> [Accessed 27 June 2021].

57 On the company's website, it is reported: 'Founded in 2015 , we are based in the UK, a state whose former and current imperialism severely impacts writers in the majority world. This position, and those of our individual members, informs our practice, which is also an ongoing exploration into alternatives - to the hierarchisation of certain languages and forms, including forms of translation; to the monoculture of globalisation; to cultural, narrative, and visual stereotypes'. See: 'About us', Tilted Axis Books, n.a. <https://www.tiltedaxispress.com/about> [Accessed 27 June 2021]. 


\section{EVALUATION}

On the basis of the above data, some considerations can be induced. In the first place, Turkey's democratic breakdown and the Kurdish issue received a much wider representation than the country's involvement in the Syrian conflict. This was one of the key events highlighted by BBC according to Cansun and Arik, but it was almost dissociated with the representation of the country in British trade publishing, or at least through the translations.

Secondly, it can be said that the translations from Turkish into English after 15 July 2016 seem influenced-even if not dominated-by Turkey's image as an increasingly illiberal country and its difficult relationship with the Kurdish minority. In subperiod two, an important share of translation was constituted by non-fiction books focusing on these themes. Many translated authors' biographies were directly connected to these issues, and British publishers used them to present a good number of translated titles.

Evidently, the fact that the above-mentioned authors and books treat about the same the socio-political themes that are exposed in this article does not mean they were translated only for this reason, and not for their literary and cultural value. This argument is also reinforced by the fact that some of them, like Burhan Sönmez, Elif Şafak, and Ahmet Altan, were already published in subperiod one. However, what can be supposed is that some Turkish authors with a stronger interest-or a stronger link in their biographies-in some socio-political issues have been privileged over others by British publishers in a period when these issues received noticeable attention by the British media system.

It must also be noted that trade publishing in the UK showed a clear position about those themes when presenting them, both in the choice of titles to translate and in the epitextual presentation: strong disapproval of the AKP and the limitations imposed by the State of Emergency; concern for the situation of the Turkish democracy; and sympathy for the Kurdish minority. This seems consistent with the critical treatment generally addressed to Erdoğan and the AKP by British media after $2016,^{58}$ the loss of soft power by Turkey due to the lower level of democracy

$58 \quad$ See for example: 'Turkey's failed coup gives its president a chance to seize more power', Economist, 16 July 2016 <https://www.economist.com/europe/2016/07/16/turkeys-failed-coup-givesits-president-a-chance-to-seize-more-power> [Accessed 13 March 2021], See also: Ranj Alaaldin, 'Aftermath of Turkey Coup Attempt Will Be Bloody and Repressive', Guardian, 16 July 2016 <https:// www.theguardian.com/world/2016/jul/16/aftermath-of-turkish-coup-attempt-will-be-bloody-andrepressive> [Accessed 13 March 2020]; See also: 'Recep Tayyip Erdogan: Turkey's Pugnacious President', BBC News, 27 October 2020 <https://www.bbc.com/news/world-europe-13746679> [Accessed 13 March 2021]. 
in the country, 59 and the criticism of the international publishing environment towards the restriction of media freedom by the Turkish government. 60

It has to be mentioned that, regarding the Western media system coverage of the coup and its aftermath, many Turkish scholars and news outlets have claimed how it was essentially biased and one-sided.61 They denounced it as 'biased journalism against the Turkish government and the conservative masses supporting it' and criticised how they only focused on the power held by the AKP at the moment of the coup and not on the violence of its plotters. ${ }^{62}$

While it is not among the objectives of this article to evaluate the coverage by UK media on the democratic crisis in Turkey, the following can be said of the behaviour of British trade publishers: in their account of the coup and its aftermath, they seemed to reflect a point of view in which the greatest risk for human rights was represented by the Turkish government and the measures contained in the SoE, which was probably deemed as graver than the coup itself. This does not necessarily mean that the UK over-simplified the issue, but that they expressed a clear ideological position while treating it.

What is certain is that the reaction of the Turkish government to the coup attempt has been disproportionate, repressive, and abusive. Therefore, the result of bringing awareness on the reality of this repression to British readers and giving voice to intellectuals who are critical about it should be attributed to UK publishers. So should be the translation of books that describe or elaborate on a crucial period of Turkey's contemporary history. Another key theme must be highlighted in this regard: the risk of this recent attention to Turkey's socio-political situation is the perception of Turkish books as 'a source of socio-political commentary or documentary, rather than as literary works per se'63 as already signalled by Tekgül and Akbatur. The risk must be considered in the frame described by Deleuze and Guattari, for which in a minor literature...

\footnotetext{
$59 \quad$ Çevik, p. 64

60 "In step with calls from the Association of Canadian Publishers and the International Publishers Association (IPA), the German Publishers and Booksellers Association (Börsenverein des Deutschen Buchhandels), PEN Centre Germany and Reporters Without Borders Germany have created a Change.org petition advocating an end to Turkish limitations on expression following the July coup attempt." Source: Porter Anderson, 'German Publishers' Petition Protests Media Constraints in Turkey', Publishing Perspectives, 31 August 2016 <https://publishingperspectives.com/2016/08/turkey-german-publishers-petition/> [Accessed 6 September 2020].
}

61 Enes Bayrakl, 'Orientalism Reloaded: How Western Media Covered the Coup Attempt in Turkey', Seta Perspective, n. 24, August 2016, pp. 1-6; See also: Erhan Içener, 'Turkey-EU Relations after the Failed July 15 Coup Attempt', Bilig, n. 79, Autumn 2016, pp. 69-87; and: 'Western media criticized over coup coverage', Anadolu Agency, 21 July $2016<$ https://www.aa.com.tr/en/europe/western-media-criticized-over-coup-coverage/612510> [Accessed 13 March 2021].

Bayraklı, p. 4.

Tekgül; updated by Akbatur, p. 9. 
everything is political. In "great" literatures, on the contrary, the question of the individual (familial, conjugal, etc.) tends to be connected to other, no less individual questions, and the social milieu serves as environment and background. [...] Minor literature is completely different: because it exists in a narrow space, every individual matter is immediately plugged into the political'. ${ }^{64}$

According to Deleuze's and Guattari's theory, Turkish literature is not a minor literature. But it can be perceived as a minor literature by the British reader at a hermeneutical stage. When inserted in the UK literary system, Turkish literature certainly shares some definition with minor literatures, such as having a 'cramped space', ${ }^{65}$ of its value being considered 'collective' ${ }^{66}$ since the Turkish writer tends to be perceived as the spokesperson of the Turkish community, and being a literature distanced from the central culture. Hence, at the hermeneutical stage, there seems to be a tangible risk of it being too politicised, of its titles with political aspects receiving more attention than others, as well as the political aspects inside its literary works being emphasised, overshadowing other compositional features.

The corpus of Turkish translations in the UK includes many genres and themes beyond contingent political events, even after 2016, and as this article highlights, most of the translations are unrelated to the country's socio-political developments. Still, what has to be taken into account is the traditionally low share of translated books in publishing. ${ }^{67}$ In the UK, one of the most important national publishing industries is represented by less than twenty translations per year, less than ten in the last two considered years. Thus, a proper representation of Turkish intellectual production in all its complexity was already unlikely before 2016. The post-coup strong focus on Turkish politics risks making the representation of the country conveyed by the UK publishing industry even less heterogeneous.

$64 \quad$ Gilles Deleuze, Félix Guattari and Robert Brinkley, 'What is a Minor Literature?'. Mississippi Review, Winter/Spring, 1983, vol. 11 n. 3, pp. 13-33, p. 16.

65 Ibid. p. 16.

$66 \quad$ Ibid. p. 17.

67 Porter Anderson, 'Nielsen Reports Translated Literature in the UK Grew 5.5 Percent in 2018', Publishing Perspectives, 6 March 2019 <https://publishingperspectives.com/2019/03/nielsen-reportstranslated-literature-in-uk-grows-5-percent-in-2018-booker/> [Accessed 13 March 2021]. 


\section{CONCLUSIONS}

After the military coup of 2016, Turkey has experienced a "democratic breakdown". The country's index of democracy and respect for human rights have worsened. This has caused a subsequent shift in the country's representation in international media, including media outlets in the UK. The central point of this article was to understand the extent to which the events interested British trade publishers, most particularly in their translations of Turkish works.

The translations from Turkish into English published in the UK from 2012 to 2019 suggest that British trade publishing has proved itself responsive to the events that have characterised Turkey in the recent years, particularly the 2016 coup attempt and the renewed conflict with the Kurdish community. The collected data suggests that 15 July 2016 has not been a complete turning point for the representation of the country by British trade publishers, but it certainly was consequential. After that date, a higher share of translations was constituted by essays, biographies, and memoirs. Four of them specifically focused on the Turkish democratic breakdown or the Kurdish issue, while no translations before 15 July 2016 regarded Turkey's broader socio-political situation.

Other influences of the new perception and representation of Turkey after the coup can be noted. In subperiod two, many translated Turkish authors were imprisoned for political reasons because they were activists or publicly hostile to the Turkish government. Moreover, an analysis on specific epitextual elementsthe books' descriptions on the UK publishers' websites-show that nine of the considered books published during subperiod two, out of thirty-six, expressly cited the coup or its aftermath, the Kurdish issue, or the Turkish intervention in the Syrian war.

Looking at the translations of subperiod two, the general outlook on the Turkish government, the Turkish President Erdoğan, and the ruling party AKP seems very negative. It has been noted that the UK publishers' position appears consistent with the one generally assumed by Western media in their coverage of the coup and its aftermath.

Finally, something highlighted in this article is the risk of presenting Turkish translations and Turkish literature in the UK as a commentary of the socio-political situation in the country, thus oversimplifying Turkish literature and culture. Even if only a minority of the translations published during subperiod two have a direct link with Turkish politics, the low number of translated books in the UK makes the risk of a low heterogeneity ratio in the representation of Turkish culture tangible. 


\section{BIBLIOGRAPHY}

'About us', Tilted Axis Books, n.a. <https://www.tiltedaxispress.com/about>

AFP (pseudonym), 'Erdogan Back in Ankara as Thousands Hit by Turkey Purge', Guardian, 20 July $2016<$ https://guardian.ng/news/erdogan-back-in-ankara-asthousands-hit-by-turkey-purge/>

Akdeniz, Yaman, and Altıparmak, Kerem, Turkey: Freedom of Expression in Jeopardy, (London: English PEN, 2018)

Alaaldin, Ranj, 'Aftermath of Turkey Coup Attempt Will Be Bloody and Repressive', Guardian, 16 July 2016 <https://www.theguardian.com/world/2016/ jul/16/aftermath-of-turkish-coup-attempt-will-be-bloody-and-repressive>

Altan, Ahmet, Like a Sword Wound (London: Europa Editions, 2018)

Altıparmak, Kerem and Gürol, Senem, 'Turkey's Derogation of Human Rights under the State of Emergency: Examining its Legitimacy and Proportionality', Austrian Review of International and European Law, Volume 22, Issue 1, pp. 101-136

Anderson, Porter 'German Publishers' Petition Protests Media Constraints in Turkey', Publishing Perspectives, 31 August $2016<$ https://publishingperspectives. com/2016/08/turkey-german-publishers-petition/>

- 'Nielsen Reports Translated Literature in the UK Grew 5.5 Percent in 2018', Publishing Perspectives, 6 March 2019 <https://publishingperspectives.com/2019/03/ nielsen-reports-translated-literature-in-uk-grows-5-percent-in-2018-booker/>

- I Will Never See the World Again (London: Granta, 2019)

Arslanalp, Mert and Erkmen, T. Deniz, 'Repression without Exception: A Study of Protest Bans during Turkey's State of Emergency (2016-2018)', South European Society and Politics, Volume 25, Issue 1, 2020 pp. 99-125

Bayraklı, Enes, 'Orientalism Reloaded: How Western Media Covered the Coup Attempt in Turkey', Seta Perspective, n. 24, August 2016, p. 1-6

'Call to Boycott Turkish Government Sponsored Academic and Cultural Institutions', Boycott Turkey, n.a. <https://boycott-turkey.net/call-to-boycott-turkishgovernment-sponsored-academic-and-cultural-institutions-2/>

Cansız, Sakine, Sara: My Whole Life Was a Struggle (London: Pluto Press, 2018)

—- Sara: Prison Memoir of a Kurdish Revolutionary (London: Pluto Press, 2019)

Cansun, Sebnem and Arik, Engin, 'Representations of countries in the international media: The case of Turkey in the BBC', Journal of the Human and Social Science Researches, Vol. 8, Issue 1, 2019, pp. 515-536

Çevik, Senem B., 'Reassessing Turkey's Soft Power: The Rules of Attraction', Alternatives: Global, Local, Political 2019, Volume 44 (1), pp. 50-71

Clark, Giles, and Phillips, Angus, Inside Book Publishing (London: Routledge, 2014) 
Cupolo, Diego, 'The State of Emergency for Turkey's Opposition', DW, 25 July 2016 <https://www.dw.com/en/the-state-of-emergency-for-turkeysopposition/a-19426590>

'Dawn', Penguin Random House, n.a. <https://www.penguinrandomhouse.com/ books/588892/dawn-by-selahattin-demirtas/>

Demirtaş, Selahattin, Dawn (London: Hogarth, 2019)

Demirtaş, Serkan, 'Has Turkey Really Lifted the State of Emergency?', Hürriyet Daily News, 10 November 2018 <https://www.hurriyetdailynews.com/opinion/serkandemirtas/has-turkey-really-lifted-the-state-of-emergency-138738>

Ellyatt, Holly, 'Turkey Lifts State of Emergency but Nothing Much Has Changed, Analysts Warn', CNBC, 19 July 2018 <https://www.cnbc.com/2018/07/19/turkey-liftsstate-of-emergency-but-nothing-much-has-changed-analysts.html>

Ercan, Harun, 'Is Hope More Precious than Victory? The Failed Peace Process and Urban Warfare in the Kurdish Region of Turkey', South Atlantic Quarterly, Vol. 118, Issue 1, 2019, pp. 110-127

'Every Fire You Tend', Tilted Axis, n.a. <https://www.tiltedaxispress.com/store/ every-fire-you-tend-paperback-preorder $>$

Fracchiolla, Domenico, 'Journalism Models in Western Democracies and the International Arena: The Case of the 2016 Failed Coup Attempt in Turkey', Partecipazione e Conflitto, Vol. 13, Issue 3, 2020, pp. 1559-1574

Genç, Kaya, Under the Shadow: Rage and Revolution in Modern Turkey (London: I.B. Taurus, 2016)

Genette, Gérard, Paratexts: Thresholds of Interpretation (Cambridge: Cambridge University Press: 1997)

Göztepe, Ece, 'The Permanency of the State of Emergency in Turkey: The Rise of a Constituent Power or only a New Quality of the State?', Z Politikwiss, Vol. 28, 2018, pp. 521-534

Grabenwarter, Christoph, Kiener, Regina, Kuijer, Martin, Porgeirsdóttir, Herdís Kjerulf, Turkey: Opinion On The Measures Provided In The Recent Emergency Decree Laws With Respect To Freedom Of The Media, (Strasbourg: European Commission for Democracy Through Law, 2017)

Gunter, Michael, 'Turkey's July 15th Coup: What Happened and Why', Middle East Policy Council <https://mepc.org/turkeys-july-15th-coup-what-happened-andwhy>

Haliloglu, Nagihan, 'Trauma, Historical Symbolism and the Return of the Repressed: The 15 July 2016 Coup Attempt in Turkey', Asian Affairs (2017), Vol. 48, Issue 1, pp. 1-16

'He's 77, Frail and Lives in Pennsylvania. Turkey Says He's a Coup Mastermind', Washington Post, 3 August 2016 < https://www. washingtonpost. com/national/hes-frail-77-and-lives-in-pennsylvania-turkey-says-hes-a-coupmastermind/2016/08/03/6blb2226-526f-1 le6-bbf5-957ad17b4385_story.htmleutm_ term $=.05 \mathrm{dcbdd} 3 \mathrm{a} 15 \mathrm{f}>$ 
'Homepage', Pluto Press, n.a. <https://www.plutobooks.com/>

'How the Turkish Purge Unfolded', Wall Street Journal, n.a. <https://www.wsj.com/ graphics/turkish-purge/>

'How to Lose a Country: The 7 Steps from Democracy to Dictatorship', Fourth Estate, n.a. <https://www.4thestate.co.uk/book/how-to-lose-a-country-the-7-stepsfrom-democracy-to-dictatorship-ece-temelkuran-9780008294045/>

'Hrant Dink: Istanbul March as Verdict Anger Continues', BBC News, 19 January 2019 <https://www.bbc.com/news/world-europe-16632890>

'I Will Never See the World Again', Granta, n.a. <https://granta.com/products/iwill-never-see-the-world-again/>

İçener, Erhan, 'Turkey-EU Relations after the Failed July 15 Coup Attempt', Bilig, $\mathrm{n}$. 79, Autumn 2016, pp. 69-87

'IPA Prix Voltaire', International Publishers Association, n.a. <https://www. internationalpublishers.org/our-work/freedom-to-publish/ipa-freedom-to-publishprize>

'Joint Statement: Turkey: State of Emergency Provisions Violate Human Rights And Should Be Revoked', Amnesty International, 19 October $2016<$ https://www. amnesty.org/en/documents/eur44/5012/2016/en/>

'Journalist Özgür Mumcu Faces Five Years in Prison for Defaming Erdoğan', Hürriyet Daily News, 5 June 2015 < https://www.hurriyetdailynews.com/journalistozgur-mumcu-faces-five-years-in-prison-for-defaming-erdogan--83518>

Karaveli, Halil M., 'The Rise and Rise of the Turkish Right', New York Times, 8 April $2019<$ https://www.nytimes.com/2019/04/08/opinion/turkey-nationalism-right-wing. html>

Kaygusuz, Sema, Every Fire You Tend (London: Tilted Axis, 2019)

Koc, Cagan and Ersoy, Ercan, 'How Turkey Created a Debt Crisis', Bloomberg, 9 December 2018 <https://www.bloomberg.com/news/features/2018-12-09/howturkey-created-a-debt-crisis $>$

'Kurdish Leader Demirtaş Remains in Prison Despite Release Orders Due to Political Pressure, Lawyer Says', Ahval, 12 September $2020<$ https://ahvalnews.com/ selahattin-demirtas/kurdish-leader-demirtas-remains-prison-despite-release-ordersdue-political? language_content_entity=en>

'Like a Sword Wound', Europa Editions, n.a. <https://www.europaeditions.com/ book/9781609454\%20746/like-a-sword-wound>

'Murdered Dink's Thoughts on Trial', English Bianet, 15 June 2007 <http://bianet. org/english/print/97671-murdered-dinks-thoughts-on-trial>

'Özgür Mumcu', Pushkin Press, n.a. <https://www.pushkinpress.com/author/ ozgur-mumcu/>

Perchoch, Philippe, Future EU-Turkey Relations (Strasburg: European Parliamentary Research Service, ([n.d.])) 
Popp, Maximilian, 'Revisiting Turkey's Failed Coup Attempt', Spiegel International, 6 July 2017 <https://www.spiegel.de/international/world/turkey-coup-a-chronologyof-events-a-1155762.html>

'Publication Archives', Freedom House, n.a. <https://freedomhouse.org/reports/ publication-archives>

'Published Works', Republic of Turkey Ministry of Culture and Tourism, n.a. <https://teda.ktb.gov.tr/EN-252216/published-works.html>

'Recep Tayyip Erdogan: Turkey's Pugnacious President', BBC news, 27 October 2020 <https://www.bbc.com/news/world-europe-13746679>

Şafak, Elif, 'Chess Is a Troubling Metaphor as Turkey Turns to the East', Financial Times, 8 January 2018 <https://www.ft.com/content/cefc19ee-ccea-1 le6-b8ceb9c03770f8bl>

'Sara: My Whole Life Was a Struggle', Pluto Press, n.a. <https://www. penguinrandomhouse.com/books/588892/dawn-by-selahattin-demirtas/>

'Sara: Prison Memoir of a Kurdish Revolutionary', Pluto Press, n.a. <https://www. plutobooks.com/9780745339832/sara/>

Scott, Allison, 'Turkey: A Market Focus', 2Seas Agency, March 2013 <https://2seasagency.com/turkey-a-land-of-publishing-opportunity/>

Sertel, Sabiha, The Struggle for Modern Turkey: Justice, Activism, and a Revolutionary Female Journalist (London: I.B. Tauris, 2019)

Shaheen, Kareem, 'Turkey Sentences Journalists to Life in Jail over Coup Attempt', The Guardian, 16 February 2018 <https://www.theguardian.com/ world/2018/feb/16/turkey-sentences-six-journalists-life-imprisonment-failed-coup>

Somer, Murat, 'Understanding Turkey's democratic breakdown: old vs. new and indigenous vs. global authoritarianism', Southeast European and Black Sea Studies, Vol. 16, 2016, pp. 448-451

Sönmez, Burhan, 'President Erdoğan Is Now Targeting Anyone Who Doesn'† Support Him', Guardian, 7 November 2016 <https://www.theguardian.com/ commentisfree/2016/nov/07/president-erdogan-turkey-leader-crackdown-mediainternet-kurdish>

'The Struggle for Modern Turkey: Justice, Activism, and a Revolutionary Female Journalist', Bloomsbury, n.a. <https://www.bloomsbury.com/us/the-struggle-formodern-turkey-9781788313575/>

Tekgül, Duygu, Literary Translation from Turkish into English in the United Kingdom and Ireland, 1990-2012, updated by Akbatur, Arzu (Aberystwyth: Literature Across Frontiers, 2013). 2016)

Temelkuran, Ece, Turkey: The Insane and the Melancholy (London: Zed Books,

_- 'Yet Again Turkey's Children Have Awoken to Darkness at Dawn', Guardian, 17 July $2016<$ https://www.theguardian.com/commentisfree/2016/jul/17/turkeychildren-coup> 
- How to Lose a Country: The 7 Steps from Democracy to Dictatorship (London: Fourth Estate, 2019)

'Turkey', Guardian, n.a. <https://www.theguardian.com/world/turkey?page=53>

'Turkey Ends State of Emergency, But Eyes Tough Terror Bill', DW, 19 July 2018 $<$ https://www.dw.com/en/turkey-ends-state-of-emergency-but-eyes-tough-terrorbill/a-44739765>

'Turkey's failed coup gives its president a chance to seize more power', The Economist, 16 July 2016 <https://www.economist.com/europe/2016/07/16/turkeysfailed-coup-gives-its-president-a-chance-to-seize-more-power>

'Turkey Post-Coup Crackdown', Turkey Purge, last updated 4 March 2019 $<$ https://turkeypurge.com/>

'Turkey Shuts Scores of Media Outlets, Sacks Generals', Al Jazeera, 27 July 2016 <https://www.aljazeera.com/news/2016/07/turkey-close-army-high-schools-failedcoup-160727165730365.html>

'Turkey Timeline: Here's How the Coup Attempt Unfolded', Al Jazeera, 16 July 2016 <https://www.aljazeera.com/news/2016/07/turkey-timeline-coup-attemptunfolded-160716004455515.html>

'Turkey: The Attempted Coup and its Troubling Aftermath', Strategic Comments, Vol. 22, Issue 5, pp. V-VII

'Unofficial Roxelana and Other Plays', Seagull Books, n.a. <https://www. seagullbooks.org/unofficial-roxelana/>

Yula, Özen, Unofficial Roxelana and Other Plays (London: Seagull Books, 2017)

Waldman, Simon and Caliskan, Emre, 'Factional and Unprofessional: Turkey's Military and the July 2016 Attempted Coup', Democracy and Security, 2020, Vol. 16, Issue 2, 123-150

'Western media criticized over coup coverage', Anadolu Agency, 21 July $2016<$ https://www.aa.com.tr/en/europe/western-media-criticized-over-coupcoverage/612510>

'Why Boycott Turkey', Boycott Turkey, n.a. <https://boycott-turkey.net/whyboycott-turkey/>

'Zed Books: Radical International Publishing', Frankfurt Rights, $2016<$ https:// frankfurtrights.com/Company/39>

Zeller, Franz and William, Stuart, 'Turkey Shuts 1,000 Schools, Arrests Wanted Cleric's Nephew', Time of Israel, 23 July 2016 <https://www.timesofisrael.com/turkeyshuts-1000-school-arrests-wanted-clerics-nephew/> 


\section{APPENDICES}

\section{Trade books translated from Turkish into English and published in the UK by a British} publisher between 1 January 2012 and 31 December 2019

Note: Academic books reported by the British Library are written in italics.

\begin{tabular}{|c|c|c|c|c|c|}
\hline Author & Title & Published & Publisher & Year & Genre \\
\hline Altun, Selçuk & $\begin{array}{l}\text { The Sultan of } \\
\text { Byzantium }\end{array}$ & London & Telegram & 2012 & $\begin{array}{l}\text { Novels/ } \\
\text { Short Stories } \\
\text { Collections }\end{array}$ \\
\hline Atasü, Erendiz & A Midlife Dream & London & Milet & 2012 & $\begin{array}{l}\text { Novels/ } \\
\text { Short Stories } \\
\text { Collections }\end{array}$ \\
\hline Collective & $\begin{array}{l}\text { Europe in } \\
\text { women's short } \\
\text { stories from } \\
\text { Turkey }\end{array}$ & London & Milet & 2012 & $\begin{array}{l}\text { Novels/ } \\
\text { Short Stories } \\
\text { Collections }\end{array}$ \\
\hline Collective & $\begin{array}{l}\text { Istanbul in } \\
\text { Women's short } \\
\text { Stories }\end{array}$ & London & Milet & 2012 & $\begin{array}{l}\text { Novels/ } \\
\text { Short Stories } \\
\text { Collections }\end{array}$ \\
\hline $\begin{array}{l}\text { Delialioglu, } \\
\text { Osman }\end{array}$ & $\begin{array}{l}2000 \text { English- } \\
\text { Turkish proverbs } \\
\text { \& idioms }\end{array}$ & Reading & $\begin{array}{l}\text { Cranmore } \\
\text { Publications }\end{array}$ & 2012 & $\begin{array}{l}\text { Novels/ } \\
\text { Short Stories } \\
\text { Collections }\end{array}$ \\
\hline $\begin{array}{l}\text { Delialoglu, } \\
\text { Osman }\end{array}$ & $\begin{array}{l}\text { Does } \\
\text { Multiculturalism } \\
\text { Work in Europe? } \\
\text { An Investigation } \\
\text { of Turkish } \\
\text { Labour Migration } \\
\text { to Germany, the } \\
\text { Integration of } \\
\text { Turkish } \\
\text { Immigrants into } \\
\text { Germany, } \\
\text { Relations } \\
\text { Between Turkey } \\
\text { and Germany }\end{array}$ & $?$ & Pichu Press & 2012 & Academic Essay \\
\hline Eroğlu, Mehmet & $\begin{array}{l}\text { The } \\
\text { Disenchanted }\end{array}$ & London & Milet & 2012 & $\begin{array}{l}\text { Essays/ } \\
\text { Biographies/ } \\
\text { Memoirs }\end{array}$ \\
\hline Ersöz, Cezmi & $\begin{array}{l}\text { Kind-hearted } \\
\text { Sinners }\end{array}$ & London & Milet & 2012 & $\begin{array}{l}\text { Novels/ } \\
\text { Short Stories }\end{array}$ \\
\hline
\end{tabular}




\begin{tabular}{|c|c|c|c|c|c|}
\hline & & & & & Collections \\
\hline $\begin{array}{l}\text { Kavukçuoğlu, } \\
\text { Deniz }\end{array}$ & $\begin{array}{l}\text { Something } \\
\text { Funny to Write } \\
\text { About }\end{array}$ & London & Milet & 2012 & $\begin{array}{l}\text { Novels/ } \\
\text { Short Stories } \\
\text { Collections }\end{array}$ \\
\hline Matur, Bejan & $\begin{array}{l}\text { How Abraham } \\
\text { Abandoned Me }\end{array}$ & Todmorden & $\begin{array}{l}\text { Arc } \\
\text { Publications }\end{array}$ & 2012 & $\begin{array}{l}\text { Novels/ } \\
\text { Short Stories } \\
\text { Collections }\end{array}$ \\
\hline Özkan, Serdar & $\begin{array}{l}\text { The Missing } \\
\text { Rose }\end{array}$ & London & Rider & 2012 & Poetry \\
\hline Pamuk, Orhan & Silent House & London & Faber & 2012 & $\begin{array}{l}\text { Novels/ } \\
\text { Short Stories } \\
\text { Collections }\end{array}$ \\
\hline $\begin{array}{l}\text { Somar, Mehmet } \\
\text { Murat }\end{array}$ & $\begin{array}{l}\text { The Serenity } \\
\text { Murders }\end{array}$ & London & Milet & 2012 & $\begin{array}{l}\text { Novels/ } \\
\text { Short Stories } \\
\text { Collections }\end{array}$ \\
\hline Soysal, Sevgi & $\begin{array}{l}\text { Noontime in } \\
\text { Yenişehir }\end{array}$ & London & Milet & 2012 & $\begin{array}{l}\text { Novels/ } \\
\text { Short Stories } \\
\text { Collections }\end{array}$ \\
\hline Aykol, Esmahan & Baksheesh & London & Bitter Lemon & 2013 & Poetry \\
\hline $\begin{array}{l}\text { Babur, Emperor } \\
\text { of Hindustan }\end{array}$ & The Baburnama & London & Folio Society & 2013 & $\begin{array}{l}\text { Novel/ } \\
\text { Short Stories }\end{array}$ \\
\hline Çalışlar, İpek & $\begin{array}{l}\text { Madam Atatürk: } \\
\text { a Biography }\end{array}$ & London & Saqi & 2013 & $\begin{array}{l}\text { Essays/ } \\
\text { Biographies/ } \\
\text { Memoirs }\end{array}$ \\
\hline Collective & $\begin{array}{l}\text { City Pick: } \\
\text { Istanbul }\end{array}$ & Hutton & $\begin{array}{l}\text { Oxygen } \\
\text { Books }\end{array}$ & 2013 & $\begin{array}{l}\text { Essays/ } \\
\text { Biographies/ } \\
\text { Memoirs }\end{array}$ \\
\hline Collective & $\begin{array}{l}\text { Turkish Poetry } \\
\text { Today } 2013\end{array}$ & $?$ & Red Hand & 2013 & $\begin{array}{l}\text { Novels/ } \\
\text { Short Stories } \\
\text { Collections }\end{array}$ \\
\hline Ersöz, Cezmi & $\begin{array}{l}\text { Confessions of a } \\
\text { Love Undone }\end{array}$ & $?$ & $\begin{array}{l}\text { Citlembik } \\
\text { Publications }\end{array}$ & 2013 & $\begin{array}{l}\text { Novels/ } \\
\text { Short Stories } \\
\text { Collections }\end{array}$ \\
\hline Inhalick, Halil & $\begin{array}{l}\text { The Ottoman } \\
\text { empire: the } \\
\text { classical age, } \\
1300-1600\end{array}$ & Cambridge & $\begin{array}{l}\text { Cambridge } \\
\text { University } \\
\text { Press }\end{array}$ & 2013 & Academic Essay \\
\hline
\end{tabular}




\begin{tabular}{|c|c|c|c|c|c|}
\hline Keskin, Birhan & $\begin{array}{l}\text { \& Silk \& Love \& } \\
\text { Flame }\end{array}$ & Todmorden & Todmorden & 2013 & $\begin{array}{l}\text { Novels/ } \\
\text { Short Stories } \\
\text { Collections }\end{array}$ \\
\hline Öze, Özkan & $\begin{array}{l}\text { I Wonder About } \\
\text { Allah }\end{array}$ & Markfield & $\begin{array}{l}\text { Islamic } \\
\text { Foundation }\end{array}$ & 2013 & Poetry \\
\hline Perker, Aslı E. & Soufflé & London & Telegram & 2013 & Religion \\
\hline Shafak, Elif & Honour & London & Penguin & 2013 & $\begin{array}{l}\text { Novels/ } \\
\text { Short Stories } \\
\text { Collections }\end{array}$ \\
\hline Tunç, Ayfer & $\begin{array}{l}\text { The Aziz Bey } \\
\text { incident: and } \\
\text { other stories }\end{array}$ & London & Istros & 2013 & $\begin{array}{l}\text { Novels/ } \\
\text { Short Stories } \\
\text { Collections }\end{array}$ \\
\hline Uzuner, Buket & I Am Istanbul & London & $\begin{array}{l}\text { Dalkey } \\
\text { Archive } \\
\text { Press }\end{array}$ & 2013 & $\begin{array}{l}\text { Novels/ } \\
\text { Short Stories } \\
\text { Collections }\end{array}$ \\
\hline Berk, İlhan & $\begin{array}{l}\text { Letters \& } \\
\text { Sounds }\end{array}$ & Gainsbourough & $\begin{array}{l}\text { Red Hand } \\
\text { Books }\end{array}$ & 2014 & Poetry \\
\hline Collective & $\begin{array}{l}\text { Aeolian } \\
\text { Visions/versions: } \\
\text { Modern Classics } \\
\text { and New Writing } \\
\text { from Turkey }\end{array}$ & London & Milet & 2014 & $\begin{array}{l}\text { Novels/ } \\
\text { Short Stories } \\
\text { Collections }\end{array}$ \\
\hline Collective & $\begin{array}{l}\text { Turkish Poetry } \\
\text { Today } 2014\end{array}$ & Gainsbourough & $\begin{array}{l}\text { Red Hand } \\
\text { Books }\end{array}$ & 2014 & $\begin{array}{l}\text { Novels/ } \\
\text { Short Stories } \\
\text { Collections }\end{array}$ \\
\hline İleri, Selim & $\begin{array}{l}\text { Boundless } \\
\text { Solitude }\end{array}$ & London & Milet & 2014 & Poetry \\
\hline İplikçi, Müge & Mount Qaf & London & Milet & 2014 & $\begin{array}{l}\text { Novels/ } \\
\text { Short Stories } \\
\text { Collections }\end{array}$ \\
\hline $\begin{array}{l}\text { Kavukçuoğlu, } \\
\text { Deniz }\end{array}$ & Zarife & London & Milet & 2014 & $\begin{array}{l}\text { Novels/ } \\
\text { Short Stories } \\
\text { Collections }\end{array}$ \\
\hline Kemal, Yaşar & $\begin{array}{l}\text { Salman the } \\
\text { Solitary }\end{array}$ & London & Harvill Press & 2014 & $\begin{array}{l}\text { Novels/ } \\
\text { Short Stories } \\
\text { Collections }\end{array}$ \\
\hline
\end{tabular}




\begin{tabular}{|c|c|c|c|c|c|}
\hline Öze, Özkan & $\begin{array}{l}\text { I Wonder About } \\
\text { Allah. Book } 2\end{array}$ & Markfield & $\begin{array}{l}\text { Islamic } \\
\text { Foundation }\end{array}$ & 2014 & $\begin{array}{l}\text { Novels/ } \\
\text { Short Stories } \\
\text { Collections }\end{array}$ \\
\hline Pamuk, Orhan & $\begin{array}{l}\text { Istanbul: } \\
\text { Memories of a } \\
\text { City }\end{array}$ & London & $\begin{array}{l}\text { Faber \& } \\
\text { Faber }\end{array}$ & 2014 & Religion \\
\hline $\begin{array}{l}\text { Ruhselman, } \\
\text { Bedri }\end{array}$ & $\begin{array}{l}\text { The Divine } \\
\text { Order and the } \\
\text { Universe }\end{array}$ & Oxford & $\begin{array}{l}\text { Divine Order } \\
\text { Publishing }\end{array}$ & 2014 & $\begin{array}{l}\text { Novels/ } \\
\text { Short Stories } \\
\text { Collections }\end{array}$ \\
\hline Shafak, Elif & $\begin{array}{l}\text { The Architect's } \\
\text { Apprentice }\end{array}$ & London & Viking & 2014 & Religion \\
\hline $\begin{array}{l}\text { Sönmez, } \\
\text { Burhan }\end{array}$ & Sins \& Innocents & Reading & $\begin{array}{l}\text { Garnet } \\
\text { Publishing }\end{array}$ & 2014 & $\begin{array}{l}\text { Novels/ } \\
\text { Short Stories } \\
\text { Collections }\end{array}$ \\
\hline $\begin{array}{l}\text { Tanpınar, } \\
\text { Ahmet Hamdi }\end{array}$ & $\begin{array}{l}\text { The Time } \\
\text { Regulation } \\
\text { Institute }\end{array}$ & London & Penguin & 2014 & $\begin{array}{l}\text { Novels/ } \\
\text { Short Stories } \\
\text { Collections }\end{array}$ \\
\hline Uzuner, Buket & Istanbul Blues & London & Milet & 2014 & $\begin{array}{l}\text { Novels/ } \\
\text { Short Stories } \\
\text { Collections }\end{array}$ \\
\hline Altan, Ahmet & Endgame & Edinburgh & Canongate & 2015 & $\begin{array}{l}\text { Novels/ } \\
\text { Short Stories } \\
\text { Collections }\end{array}$ \\
\hline Aral, İnci & Saffron Yellow & London & $\begin{array}{l}\text { Thames River } \\
\text { Press }\end{array}$ & 2015 & $\begin{array}{l}\text { Novels/ } \\
\text { Short Stories } \\
\text { Collections }\end{array}$ \\
\hline Aykol, Esmahan & $\begin{array}{l}\text { Divorce Turkish } \\
\text { Style }\end{array}$ & London & $\begin{array}{l}\text { Bitter Lemon } \\
\text { Press }\end{array}$ & 2015 & $\begin{array}{l}\text { Novels/ } \\
\text { Short Stories } \\
\text { Collections }\end{array}$ \\
\hline Collective & $\begin{array}{l}\text { Turkish Poetry } \\
\text { Today } 2015\end{array}$ & Gainsbourough & $\begin{array}{l}\text { Red Hand } \\
\text { Books }\end{array}$ & 2015 & $\begin{array}{l}\text { Novels/ } \\
\text { Short Stories } \\
\text { Collections }\end{array}$ \\
\hline Gunes, Aysenur & $\begin{array}{l}\text { All about Prayer } \\
\text { (Salah) Activity } \\
\text { Book: } \\
\text { Discover Islam } \\
\text { Sticker Activity }\end{array}$ & Markfield & $\begin{array}{l}\text { Islamic } \\
\text { Foundation }\end{array}$ & 2015 & Religion \\
\hline
\end{tabular}




\begin{tabular}{|c|c|c|c|c|c|}
\hline Gunes, Aysenur & $\begin{array}{l}\text { Makkah and } \\
\text { Madinah Activity } \\
\text { Book: } \\
\text { Discover Islam } \\
\text { Sticker Activity } \\
\text { Books }\end{array}$ & Markfield & $\begin{array}{l}\text { Islamic } \\
\text { Foundation }\end{array}$ & 2015 & Religion \\
\hline Gunes, Aysenur & $\begin{array}{l}\text { Mosques of the } \\
\text { World Activity } \\
\text { Book: } \\
\text { Discover Islam } \\
\text { Sticker Activity } \\
\text { Book }\end{array}$ & Markfield & $\begin{array}{l}\text { Islamic } \\
\text { Foundation }\end{array}$ & 2015 & Religion \\
\hline $\begin{array}{l}\text { Hepçilingirler, } \\
\text { Feyza }\end{array}$ & $\begin{array}{l}\text { As the Red } \\
\text { Carnation Fades }\end{array}$ & London & Milet & 2015 & $\begin{array}{l}\text { Novels/ } \\
\text { Short Stories } \\
\text { Collections }\end{array}$ \\
\hline $\begin{array}{l}\text { Hoca, } \\
\text { Nasreddin }\end{array}$ & $\begin{array}{l}\text { Tales of the } \\
\text { Turkish Trickster }\end{array}$ & London & ReadZone & 2015 & $\begin{array}{l}\text { Novels/ } \\
\text { Short Stories } \\
\text { Collections }\end{array}$ \\
\hline İlhan, Çiler & Exile & London & Istros & 2015 & $\begin{array}{l}\text { Novels/ } \\
\text { Short Stories } \\
\text { Collections }\end{array}$ \\
\hline İrepoğlu, Gül & $\begin{array}{l}\text { Unto the Tulip } \\
\text { Gardens: My } \\
\text { Shadow }\end{array}$ & London & $\begin{array}{l}\text { Thames River } \\
\text { Press }\end{array}$ & 2015 & $\begin{array}{l}\text { Novels/ } \\
\text { Short Stories } \\
\text { Collections }\end{array}$ \\
\hline $\begin{array}{l}\text { Kaygusuz, } \\
\text { Sema }\end{array}$ & $\begin{array}{l}\text { The Well of } \\
\text { Trapped Words: } \\
\text { Selected Stories }\end{array}$ & Manchester & Comma & 2015 & $\begin{array}{l}\text { Novels/ } \\
\text { Short Stories } \\
\text { Collections }\end{array}$ \\
\hline Özyüksel, Murat & $\begin{array}{l}\text { The Hejaz } \\
\text { Railway and the } \\
\text { Ottoman } \\
\text { Empire: } \\
\text { Modernity, } \\
\text { Industrialisation } \\
\text { and Ottoman } \\
\text { decline }\end{array}$ & London & I.B. Tauris & 2015 & Academic Essay \\
\hline Pamuk, Orhan & $\begin{array}{l}\text { A Strangeness } \\
\text { in My Mind }\end{array}$ & London & $\begin{array}{l}\text { Faber \& } \\
\text { Faber }\end{array}$ & 2015 & $\begin{array}{l}\text { Novels/ } \\
\text { Short Stories } \\
\text { Collections }\end{array}$ \\
\hline $\begin{array}{l}\text { Toptaş, Hasan } \\
\text { Ali }\end{array}$ & Reckless & London & Bloomsbury & 2015 & $\begin{array}{l}\text { Novels/ } \\
\text { Short Stories } \\
\text { Collections }\end{array}$ \\
\hline
\end{tabular}




\begin{tabular}{|c|c|c|c|c|c|}
\hline Turan, Güven & $\begin{array}{l}\text { Secret domain: } \\
\text { A Poem } \\
\text { Sequence }\end{array}$ & London & $\begin{array}{l}\text { Red Hand } \\
\text { Books }\end{array}$ & 2015 & Poetry \\
\hline Ture, Fatma & $\begin{array}{l}\text { Facts and } \\
\text { fantasies: } \\
\text { Images of } \\
\text { Istanbul Women } \\
\text { in the 1920s }\end{array}$ & $\begin{array}{l}\text { Newcastle } \\
\text { upon Tyne }\end{array}$ & $\begin{array}{l}\text { Cambridge } \\
\text { Scholars }\end{array}$ & 2015 & $\begin{array}{l}\text { Essays/ } \\
\text { Biographies/ } \\
\text { Memoirs }\end{array}$ \\
\hline Vahapoğlu, Ece & The Other & London & $\begin{array}{l}\text { Thames River } \\
\text { Press }\end{array}$ & 2015 & $\begin{array}{l}\text { Novels/ } \\
\text { Short Stories } \\
\text { Collections }\end{array}$ \\
\hline Yaşar, Kemal & $\begin{array}{l}\text { Birds Have Also } \\
\text { Gone }\end{array}$ & London & Harvill Press & 2015 & $\begin{array}{l}\text { Novels/ } \\
\text { Short Stories } \\
\text { Collections }\end{array}$ \\
\hline Yaşar, Kemal & $\begin{array}{l}\text { Iron Earth, } \\
\text { Copper Sky }\end{array}$ & London & Harvill Press & 2015 & $\begin{array}{l}\text { Novels/ } \\
\text { Short Stories } \\
\text { Collections }\end{array}$ \\
\hline Yaşar, Kemal & $\begin{array}{l}\text { The Undying } \\
\text { Grass }\end{array}$ & London & $\begin{array}{l}\text { Vintage } \\
\text { Digital }\end{array}$ & 2015 & Poetry \\
\hline Yaşar, Kemal & $\begin{array}{l}\text { To Crush the } \\
\text { Serpent }\end{array}$ & London & Harvill Press & 2015 & $\begin{array}{l}\text { Novels/ } \\
\text { Short Stories } \\
\text { Collections }\end{array}$ \\
\hline Altaylı, Enver & $\begin{array}{l}\text { A Dark Path to } \\
\text { freedom: Ruzi } \\
\text { Nazar, from the } \\
\text { Red Army to the } \\
\text { CIA }\end{array}$ & London & Hurst & 2017 & $\begin{array}{l}\text { Essays/ } \\
\text { Biographies/ } \\
\text { Memoirs }\end{array}$ \\
\hline Atay, Oğuz & $\begin{array}{l}\text { The } \\
\text { Disconnected }\end{array}$ & London & Olric & 2017 & $\begin{array}{l}\text { Novels/ } \\
\text { Short Stories } \\
\text { Collections }\end{array}$ \\
\hline Çapan, Cevat & $\begin{array}{l}\text { The Voice of } \\
\text { Water }\end{array}$ & London & $\begin{array}{l}\text { Arc } \\
\text { Publications }\end{array}$ & 2017 & Poetry \\
\hline Collective & $\begin{array}{l}\text { Turkish Poetry } \\
\text { Today } 2017\end{array}$ & $?$ & $\begin{array}{l}\text { Red Hand } \\
\text { Books }\end{array}$ & 2017 & Poetry \\
\hline Gunes, Aysenur & $\begin{array}{l}\text { All About Wudu } \\
\text { Activity Book }\end{array}$ & Markfield & $\begin{array}{l}\text { Central ; } \\
\text { Islamic } \\
\text { Foundation }\end{array}$ & 2017 & Religion \\
\hline $\begin{array}{l}\text { Güzelce, Bedia } \\
\text { Ceylan }\end{array}$ & 1473 & London & $\begin{array}{l}\text { Kingston } \\
\text { University } \\
\text { Press }\end{array}$ & 2017 & $\begin{array}{l}\text { Novels/ } \\
\text { Short Stories } \\
\text { Collections }\end{array}$ \\
\hline
\end{tabular}




\begin{tabular}{|c|c|c|c|c|c|}
\hline Karakaşlı, Karin & $\begin{array}{l}\text { History- } \\
\text { Geography }\end{array}$ & London & $\begin{array}{l}\text { Poetry } \\
\text { Translation } \\
\text { Centre }\end{array}$ & 2017 & Poetry \\
\hline $\begin{array}{l}\text { Markosean, } \\
\text { Mkrtich }\end{array}$ & $\begin{array}{l}\text { Gâvur } \\
\text { Mahallesi :Infidel } \\
\text { Quarter }\end{array}$ & London & $\begin{array}{l}\text { Gomidas } \\
\text { Institute }\end{array}$ & 2017 & Poetry \\
\hline Matur, Bejan & $\begin{array}{l}\text { If This is a } \\
\text { Lament }\end{array}$ & London & $\begin{array}{l}\text { Poetry } \\
\text { Translation } \\
\text { Centre }\end{array}$ & 2017 & Poetry \\
\hline Öze, Özkan & $\begin{array}{l}\text { I Wonder about } \\
\text { the Qur'an }\end{array}$ & Markfield & $\begin{array}{l}\text { Islamic } \\
\text { Foundation }\end{array}$ & 2017 & Religion \\
\hline Pamuk, Orhan & $\begin{array}{l}\text { The Red-Haired } \\
\text { Woman }\end{array}$ & Rearsby & W F Howes & 2017 & $\begin{array}{l}\text { Novels/ } \\
\text { Short Stories } \\
\text { Collections }\end{array}$ \\
\hline $\begin{array}{l}\text { Temelkuran, } \\
\text { Ece }\end{array}$ & $\begin{array}{l}\text { Women Who } \\
\text { Blow on Knots }\end{array}$ & Cardigan & Parthian & 2017 & $\begin{array}{l}\text { Novels/ } \\
\text { Short Stories } \\
\text { Collections }\end{array}$ \\
\hline $\begin{array}{l}\text { Toptaş, Hasan } \\
\text { Ali }\end{array}$ & Shadowless & London & Bloomsbury & 2017 & $\begin{array}{l}\text { Novels/ } \\
\text { Short Stories } \\
\text { Collections }\end{array}$ \\
\hline Yula, Özen & $\begin{array}{l}\text { Unofficial } \\
\text { Roxelana and } \\
\text { other plays }\end{array}$ & London & Seagull & 2017 & $\begin{array}{l}\text { Essays/ } \\
\text { Biographies/ } \\
\text { Memoirs }\end{array}$ \\
\hline Altan, Ahmet & $\begin{array}{l}\text { Like a Sword } \\
\text { Wound }\end{array}$ & Brentwood & Europa & 2018 & $\begin{array}{l}\text { Novel/ } \\
\text { Short Stories } \\
\text { Collections }\end{array}$ \\
\hline Cansız, Sakine & $\begin{array}{l}\text { Sara: My Whole } \\
\text { Life Was a } \\
\text { Struggle }\end{array}$ & London & Pluto Press & 2018 & $\begin{array}{l}\text { Essays/ } \\
\text { Biographies/ } \\
\text { Memoirs }\end{array}$ \\
\hline Elmasoglu, Fadl & $\begin{array}{l}\text { The Battle of } \\
\text { Kokkina: } \\
\text { Erenköy Ve } \\
\text { Hayat: The } \\
\text { Memoirs of Fadil } \\
\text { Elmas }\end{array}$ & $\begin{array}{l}\text { Kibworth } \\
\text { Beauchamp }\end{array}$ & Matador & 2018 & $\begin{array}{l}\text { Essays/ } \\
\text { Biographies/ } \\
\text { Memoirs }\end{array}$ \\
\hline $\begin{array}{l}\text { Işın, Priscilla } \\
\text { Mary }\end{array}$ & $\begin{array}{l}\text { Bountiful Empire } \\
\text { A History of } \\
\text { Ottoman Cuisine }\end{array}$ & London & $\begin{array}{l}\text { Reaktion } \\
\text { Books }\end{array}$ & 2018 & $\begin{array}{l}\text { Essays/Biographies/ } \\
\text { Memoirs }\end{array}$ \\
\hline Mumcu, Oz̈gür & $\begin{array}{l}\text { The Peace } \\
\text { Machine }\end{array}$ & London & Pushkin & 2018 & $\begin{array}{l}\text { Novels/ } \\
\text { Short Stories }\end{array}$ \\
\hline
\end{tabular}




\begin{tabular}{|c|c|c|c|c|c|}
\hline Pamuk, Orhan & $\begin{array}{l}\text { The Innocence } \\
\text { of Memories }\end{array}$ & London & $\begin{array}{l}\text { Faber \& } \\
\text { Faber }\end{array}$ & 2018 & $\begin{array}{l}\text { Novel/ } \\
\text { Short Stories } \\
\text { Collections }\end{array}$ \\
\hline $\begin{array}{l}\text { Tanpınar, } \\
\text { Ahmet Hamdi }\end{array}$ & $\begin{array}{l}\text { Tanpinar's 'Five } \\
\text { Cities' }\end{array}$ & London & Anthem & 2018 & $\begin{array}{l}\text { Essays/ } \\
\text { Biographies/ } \\
\text { Memoirs }\end{array}$ \\
\hline Altan, Ahmet & $\begin{array}{l}\text { I Will Never See } \\
\text { the World Again }\end{array}$ & London & Granta & 2019 & $\begin{array}{l}\text { Essays/ } \\
\text { Biographies/ } \\
\text { Memoirs }\end{array}$ \\
\hline Cansız, Sakine & $\begin{array}{l}\text { Sara: Prison } \\
\text { Memoir of a } \\
\text { Kurdish } \\
\text { Revolutionary }\end{array}$ & London & Pluto Press & 2019 & $\begin{array}{l}\text { Essays/ } \\
\text { Biographies/ } \\
\text { Memoirs }\end{array}$ \\
\hline $\begin{array}{l}\text { Demirtaş, } \\
\text { Selahattin }\end{array}$ & Dawn & London & Hogarth & 2019 & $\begin{array}{l}\text { Novels/ } \\
\text { Short Stories } \\
\text { Collections }\end{array}$ \\
\hline $\begin{array}{l}\text { Günyol, Özlem } \\
\text { \& Kunt, Mustafa }\end{array}$ & $\begin{array}{l}\text { Ozlem Gunyol \& } \\
\text { Mustafa Kunt }\end{array}$ & Milton Park & $\begin{array}{l}\text { Dirimart; } \\
\text { Marston Book } \\
\text { Services }\end{array}$ & 2019 & Art \\
\hline $\begin{array}{l}\text { Kaygusuz, } \\
\text { Sema }\end{array}$ & $\begin{array}{l}\text { Every Fire You } \\
\text { Tend }\end{array}$ & London & $\begin{array}{l}\text { Tilted Axis } \\
\text { Press }\end{array}$ & 2019 & $\begin{array}{l}\text { Novels/ } \\
\text { Short Stories } \\
\text { Collections }\end{array}$ \\
\hline Kesal, Ercan & $\begin{array}{l}\text { Fairy Chimney } \\
\text { Soda }\end{array}$ & London & Anthem & 2019 & $\begin{array}{l}\text { Novels/ } \\
\text { Short Stories } \\
\text { Collections }\end{array}$ \\
\hline Sertel, Sabiha & $\begin{array}{l}\text { The struggle for } \\
\text { Modern Turkey: } \\
\text { Justice, Activism } \\
\text { and a } \\
\text { Revolutionary } \\
\text { Female } \\
\text { Journalist }\end{array}$ & London & I.B. Tauris & 2019 & $\begin{array}{l}\text { Essays/ } \\
\text { Biographies/ } \\
\text { Memoirs }\end{array}$ \\
\hline Ümit, Ahmet & $\begin{array}{l}\text { Farewell, my } \\
\text { Beautiful } \\
\text { Homeland }\end{array}$ & London & Anthem & 2019 & $\begin{array}{l}\text { Novels/ } \\
\text { Short Stories } \\
\text { Collections }\end{array}$ \\
\hline Berk, İlhan & $\begin{array}{l}\text { New Selected } \\
\text { Poems 1947- } \\
2008\end{array}$ & Exeter & Shearsman & $\begin{array}{l}2016 \\
\text { (before } \\
15 \\
\text { July) }\end{array}$ & Poetry \\
\hline $\begin{array}{l}\text { Bursevi, İsmail } \\
\text { Hakkı }\end{array}$ & $\begin{array}{l}\text { Ibn 'Arabi's } \\
\text { Kernel of the } \\
\text { Kernel }\end{array}$ & Cheltenham & $\begin{array}{l}\text { Beshara } \\
\text { Publications }\end{array}$ & $\begin{array}{l}2016 \\
\text { (before }\end{array}$ & Religion \\
\hline
\end{tabular}




\begin{tabular}{|c|c|c|c|c|c|}
\hline $\begin{array}{l}\text { Bursevi, İsmail } \\
\text { Hakkı }\end{array}$ & $\begin{array}{l}\text { Ibn 'Arabi's } \\
\text { Kernel of the } \\
\text { Kernel }\end{array}$ & Cheltenham & $\begin{array}{l}\text { Beshara } \\
\text { Publications }\end{array}$ & $\begin{array}{l}2016 \\
\text { (before } \\
15 \\
\text { July) }\end{array}$ & Religion \\
\hline Collective & $\begin{array}{l}\text { Turkish Poetry } \\
\text { Today } 2016\end{array}$ & Gainsbourough & $\begin{array}{l}\text { Red Hand } \\
\text { Books }\end{array}$ & $\begin{array}{l}2016 \\
\text { (post } \\
15 \\
\text { July) }\end{array}$ & Poetry \\
\hline Gunes, Aysenur & $\begin{array}{l}\text { Ramadan and } \\
\text { Fasting Activity } \\
\text { Book: } \\
\text { Discover Islam } \\
\text { Sticker Activity } \\
\text { Book }\end{array}$ & Markfield & $\begin{array}{l}\text { Islamic } \\
\text { Foundation }\end{array}$ & $\begin{array}{l}2016 \\
\text { (before } \\
15 \\
\text { July) }\end{array}$ & Religion \\
\hline $\begin{array}{l}\text { Kâmuran, } \\
\text { Solmaz }\end{array}$ & Kiraze & Reading & Garnet & $\begin{array}{l}2016 \\
\text { (before } \\
15 \\
\text { July) }\end{array}$ & $\begin{array}{l}\text { Novels/ } \\
\text { Short Stories } \\
\text { Collections }\end{array}$ \\
\hline $\begin{array}{l}\text { Kanık, Orhan } \\
\text { Veli }\end{array}$ & $\begin{array}{l}\text { The Complete } \\
\text { Poems }\end{array}$ & Bristol & Shearsman & $\begin{array}{l}2016 \\
\text { (post } \\
15 \\
\text { July) }\end{array}$ & Poetry \\
\hline Öze, Özkan & $\begin{array}{l}\text { I Wonder About } \\
\text { the Prophet. } \\
\text { Book } 3\end{array}$ & Markfield & $\begin{array}{l}\text { Islamic } \\
\text { Foundation }\end{array}$ & $\begin{array}{l}2016 \\
\text { (before } \\
15 \\
\text { July) }\end{array}$ & Religion \\
\hline Sabahattin Ali & $\begin{array}{l}\text { Madonna in a } \\
\text { Fur Coat }\end{array}$ & London & Penguin & $\begin{array}{l}2016 \\
\text { (before } \\
15 \\
\text { July) }\end{array}$ & $\begin{array}{l}\text { Novels/ } \\
\text { Short Stories } \\
\text { Collections }\end{array}$ \\
\hline Shafak, Elif & $\begin{array}{l}\text { Three Daughters } \\
\text { of Eve }\end{array}$ & London & Viking & $\begin{array}{l}2016 \\
\text { (post } \\
15 \\
\text { July) }\end{array}$ & $\begin{array}{l}\text { Novels/ } \\
\text { Short Stories } \\
\text { Collections }\end{array}$ \\
\hline $\begin{array}{l}\text { Sönmez, } \\
\text { Burhan }\end{array}$ & $\begin{array}{l}\text { Istanbul, } \\
\text { Istanbul }\end{array}$ & London & Telegram & $\begin{array}{l}2016 \\
\text { (post } \\
15 \\
\text { July) }\end{array}$ & $\begin{array}{l}\text { Novels/ } \\
\text { Short Stories } \\
\text { Collections }\end{array}$ \\
\hline $\begin{array}{l}\text { Temelkuran, } \\
\text { Ece }\end{array}$ & $\begin{array}{l}\text { Turkey: The } \\
\text { Insane and the } \\
\text { Melancholy }\end{array}$ & London & Zed Books & $\begin{array}{l}2016 \\
\text { (post } \\
15 \\
\text { July) }\end{array}$ & $\begin{array}{l}\text { Essays/ } \\
\text { Biographies/ } \\
\text { Memoirs }\end{array}$ \\
\hline Uzuner, Buket & $\begin{array}{l}\text { Two Green } \\
\text { Otters }\end{array}$ & Horsham & $\begin{array}{l}\text { Milet } \\
\text { Publishing }\end{array}$ & $\begin{array}{l}2016 \\
\text { (before } \\
15 \\
\text { July) }\end{array}$ & $\begin{array}{l}\text { Novels/ } \\
\text { Short Stories } \\
\text { Collections }\end{array}$ \\
\hline
\end{tabular}




\begin{tabular}{|l|l|l|l|l|l|}
\hline Yaşar Kemal & $\begin{array}{l}\text { The Sea- } \\
\text { crossed } \\
\text { Fisherman }\end{array}$ & London & $\begin{array}{l}\text { Vintage } \\
\text { Digital }\end{array}$ & $\begin{array}{l}2016 \\
\text { (before } \\
15 \\
\text { July) }\end{array}$ & $\begin{array}{l}\text { Novels/ } \\
\text { Short Stories } \\
\text { Collections }\end{array}$ \\
\hline Yaşar Kemal & $\begin{array}{l}\text { They Burn } \\
\text { Thistles }\end{array}$ & London & Vintage & $\begin{array}{l}2016 \\
\text { (post } \\
15\end{array}$ & Sovels/ \\
July) & Short Stories \\
\hline
\end{tabular}

